


\section{Onderzoek naar het voorkomen van de wasbeer in Nederland}

E.A. van der Grift, D.R. Lammertsma, H.A.H. Jansman en R.M.A. Wegman

Dit onderzoek is uitgevoerd door Alterra Wageningen UR in opdracht van en gefinancierd door de Nederlandse Voedsel- en Warenautoriteit van het ministerie van Economische Zaken.

Wageningen Environmental Research

Wageningen, november 2016

Rapport 2764

ISSN 1566-7197 
Van der Grift, E.A., D.R. Lammertsma, H.A.H. Jansman en R.M.A. Wegman, 2016. Onderzoek naar het voorkomen van de wasbeer in Nederland. Wageningen, Wageningen Environmental Research, Rapport 2764. 44 blz.; 20 fig.; 1 tab.; 26 ref.

In opdracht van het Bureau Risicobeoordeling en onderzoeksprogrammering (BuRO) van de Nederlandse Voedsel- en Warenautoriteit (NVWA) is het voorkomen van de Wasbeer (Procyon lotor) in Nederland en de Duitse grensstreek in beeld gebracht en onderzocht of er sprake is van gevestigde populaties. Vooralsnog zijn er geen aanwijzingen dat er binnen Nederland sprake is van een lokaal gevestigde populatie. In de Duitse grensstreek met Nederland zijn de aantallen nog relatief laag, maar als de huidige populatietrends doorzetten, verandert dat naar verwachting op korte termijn. Hoewel concrete gegevens ontbreken, is de kans groot dat inmiddels, op een aantal plaatsen, gevestigde populaties dicht bij de Nederlandse landsgrens voorkomen.

On request of the Bureau Risicobeoordeling en onderzoeksprogrammering (BuRO) of the Nederlandse Voedsel- en Warenautoriteit (NVWA) the occurrence of the Raccoon (Procyon lotor) in the Netherlands and bordering areas in Germany has been researched as well as whether established populations are present. Currently there is no evidence for established populations of Raccoon within the Netherlands. In Gemany Raccoon numbers are still relatively low along the Dutch border, however, this may change soon if the current population growth rates will maintain. Although no specific data are available, chances are high that, at least at a few locations, established populations occur on the German side of the border.

Trefwoorden: wasbeer, Procyon lotor, verspreiding, Nederland, Duitsland, Doetinchem, Biesbosch

Dit rapport is gratis te downloaden van http://dx.doi.org/10.18174/396697 of op www.wur.nl/environmental-research (ga naar 'Wageningen Environmental Research' in de grijze balk onderaan). Wageningen Environmental Research verstrekt geen gedrukte exemplaren van rapporten.

2016 Wageningen Environmental Research (instituut binnen de rechtspersoon Stichting Wageningen Research), Postbus 47, 6700 AA Wageningen, T 03174807 00, E info.alterra@wur.nl, www.wur.nl/environmental-research. Wageningen Environmental Research is onderdeel van Wageningen University \& Research.

- Overname, verveelvoudiging of openbaarmaking van deze uitgave is toegestaan mits met duidelijke bronvermelding.

- Overname, verveelvoudiging of openbaarmaking is niet toegestaan voor commerciële doeleinden en/of geldelijk gewin.

- Overname, verveelvoudiging of openbaarmaking is niet toegestaan voor die gedeelten van deze uitgave waarvan duidelijk is dat de auteursrechten liggen bij derden en/of zijn voorbehouden.

Wageningen Environmental Research aanvaardt geen aansprakelijkheid voor eventuele schade voortvloeiend uit het gebruik van de resultaten van dit onderzoek of de toepassing van de adviezen.

Wageningen Environmental Research Rapport 2764 | ISSN 1566-7197

Foto omslag: jadimages (shutterstock) 


\section{Inhoud}

$\begin{array}{ll}\text { Samenvatting } & 5\end{array}$

1

$\begin{array}{ll}\text { Inleiding } & 7\end{array}$

$\begin{array}{lll}1.1 & \text { Achtergrond } & 7\end{array}$

$\begin{array}{lll}1.2 & \text { Doel van het onderzoek } & 7\end{array}$

$\begin{array}{lll}1.3 & \text { Werkwijze } & 7\end{array}$

2

$\begin{array}{ll}\text { Wasberen in Nederland } & 8\end{array}$

$\begin{array}{lll}2.1 & \text { Inleiding } & 8\end{array}$

2.2 Methode $\quad 8$

2.3 Resultaat 9

2.3.1 Verspreiding in Nederland 9

2.3.2 Kansrijke locaties voor lokaal gevestigde populaties $\quad 13$

$\begin{array}{lll}2.4 & \text { Conclusies } & 14\end{array}$

$3 \quad$ Wasberen in de Duitse grensstreek $\quad 15$

$\begin{array}{lll}3.1 & \text { Inleiding } & 15\end{array}$

3.2 Methode $\quad 15$

$\begin{array}{lll}3.3 & \text { Resultaat } & 15\end{array}$

3.3.1 Verspreiding in Duitsland $\quad 15$

3.3.2 Populaties in Niedersachsen 16

$\begin{array}{ll}\text { 3.3.3 Populaties in Nordrhein-Westfalen } & 17\end{array}$

$\begin{array}{lll}3.4 & \text { Conclusies } & 19\end{array}$

4 Veldinventarisatie Doetinchem $r$

$\begin{array}{lll}4.1 & \text { Inleiding } & 20\end{array}$

$\begin{array}{lll}4.2 \text { Methode } & 20\end{array}$

$\begin{array}{ll}\text { 4.2.1 Afbakening studiegebied } & 20\end{array}$

$\begin{array}{ll}4.2 .2 \text { Infrarood-cameravallen } & 20\end{array}$

$\begin{array}{ll}4.2 .3 \text { Sporenonderzoek } & 23\end{array}$

$\begin{array}{ll}4.2 .4 \text { Buurtonderzoek } & 24\end{array}$

$\begin{array}{ll}4.2 .5 \text { Vaststellen reproductie } & 24\end{array}$

$\begin{array}{lll}4.3 & \text { Resultaat } & 25\end{array}$

$\begin{array}{lll}4.4 & \text { Conclusies } & 25\end{array}$

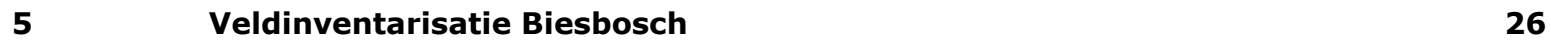

$\begin{array}{lll}5.1 & \text { Inleiding } & 26\end{array}$

$\begin{array}{ll}5.2 \text { Methode } & 26\end{array}$

5.2.1 Afbakening studiegebied $\quad 26$

5.2.2 Infrarood-cameravallen 26

$\begin{array}{ll}5.2 .3 \text { Sporenonderzoek } & 26\end{array}$

$\begin{array}{ll}5.2 .4 \text { Vaststellen reproductie } & 27\end{array}$

$\begin{array}{lll}5.3 & \text { Resultaat } & 27\end{array}$

$\begin{array}{lll}5.4 & \text { Conclusies } & 28\end{array}$

6

$\begin{array}{ll}\text { Aanbevelingen } & \mathbf{3 0}\end{array}$

$\begin{array}{ll}\text { Dankwoord } & 31\end{array}$

$\begin{array}{ll}\text { Literatuur } & 32\end{array}$ 
Bijlage 1 Homeranges Wasbeer

Bijlage 2 Recente meldingen van Wasberen in Nederland

Bijlage 3 Waarnemingen van Wasberen in België

Bijlage 4 Contacten Duitsland 38

Bijlage 5 Afschot/valwild in Duitsland 39

Bijlage 6 Aantal valnachten 40

Bijlage 7 Info-sheet buurtonderzoek 


\section{Samenvatting}

Momenteel komt de Wasbeer (Procyon lotor) incidenteel voor in Nederland. De herkomst van de dieren is vaak onduidelijk. Meestal gaat het om verkeersslachtoffers, maar er zijn ook meldingen van levende dieren of pootafdrukken. Het betreft naar verwachting vooral dieren die zijn uitgezet of ontsnapt. Daarnaast bestaat de kans dat Wasberen ons land binnenkomen vanuit Duitsland of België. Er zijn momenteel nog geen bewijzen voor een gevestigde populatie binnen onze landsgrenzen. De vondst van meerdere (aangereden) dieren op korte afstand van elkaar binnen een relatief korte tijdsperiode kan hier echter wel op wijzen. Zo zijn er recent drie dode Wasberen gevonden nabij Doetinchem. Omdat Wasberen exoten zijn en daarbij een potentieel gevaar voor de volksgezondheid kunnen vormen door de parasieten die ze bij zich dragen, wil Bureau Risicobeoordeling en onderzoeksprogrammering (BuRO) van de Nederlandse Voedsel- en Warenautoriteit (NVWA) meer inzicht krijgen in de verspreiding en mogelijke vestiging van de Wasbeer in Nederland en de Duitse grensstreek.

Het doel van het onderzoek is het voorkomen van de Wasbeer in Nederland en de Duitse grensstreek in beeld te brengen en te onderzoeken of er sprake is van gevestigde populaties. Een populatie wordt als 'gevestigd' aangemerkt als er lokaal succesvolle reproductie heeft plaatsgevonden. De onderzoeksvragen zijn concreet:

1. Zijn in de periode 2009-2015 geregistreerde meldingen van Wasberen in Nederland gerelateerd aan lokaal gevestigde populaties?

2. Zijn wasberen aanwezig in het grensgebied met Duitsland, en gaat het hierbij om lokaal gevestigde populaties?

3. Komen er in de omgeving van de recente vindplaatsen bij Doetinchem meer Wasberen voor en zo ja: is er sprake van een lokaal gevestigde populatie en hoe groot is het areaal van deze populatie?

Om de eerste onderzoeksvraag te beantwoorden, is een verspreidingsbeeld voor de Wasbeer in Nederland vervaardigd voor de periode 2009-2015. Vervolgens is met behulp van enkele beslisregels geanalyseerd of er plekken zijn waar het voorkomen van een lokaal gevestigde populatie kansrijk is. In de periode 2009-2015 zijn er regelmatig Wasberen gezien in Nederland: in totaal zijn er in deze periode 90 waarnemingen van een Wasbeer geregistreerd. Hiervan zijn er 60 geclassificeerd als zeker en 30 als onzeker. De aantallen variëren sterk per jaar. In 2011 zijn de minste waarnemingen gedaan $(n=5)$ en in 2014 de meeste $(n=22)$. Er is geen duidelijke trend - positief of negatief - te zien in de geregistreerde aantallen tussen 2009 en 2015. De waarnemingen komen uit nagenoeg alle delen van het land, met uitzondering van Zeeland en de Waddeneilanden. Dit verspreidingsbeeld suggereert dat de meeste waarnemingen ontsnapte of losgelaten huisdieren betreffen. Dit kan ook de sterke variatie tussen jaren verklaren, want als de waarnemingen vooral een gevolg zijn van een gestage instroom van Wasberen vanuit de bestaande populaties in Duitsland zijn minder variatie en een duidelijke stijgende trend te verwachten.

Op basis van de geregistreerde meldingen van Wasberen in Nederland in de periode 2009-2015 zijn er twee locaties aan te wijzen die kansrijk zijn voor een lokaal gevestigde populatie. Dit betreft de omgeving van Doetinchem en de Dordtse Biesbosch. In beide gebieden is daarom een veldinventarisatie uitgevoerd. Hierbij is gebruikgemaakt van cameravallen, sporenonderzoek en buurtonderzoek. Tijdens het onderzoek zijn in de omgeving van Doetinchem geen Wasberen geregistreerd met de cameravallen en het sporenonderzoek. Door buurtbewoners gemelde pootafdrukken in Gaanderen zijn geclassificeerd als 'mogelijk van een Wasbeer'. Het voorkomen van de Wasbeer in de Dordtse Biesbosch is tijdens de inventarisatie bevestigd. Naar verwachting gaat het om één individu, een volwassen man. Dit dier is op drie uiteenlopende plekken in de Dordtse Biesbosch waargenomen, wat suggereert dat het dier dit hele moerasgebied als leefgebied heeft. Er zijn geen aanwijzingen dat er in de omgeving van Doetinchem en de Dordtse Biesbosch sprake is van een lokaal gevestigde populatie. 
De huidige verspreiding van de Wasbeer in de Duitse grensstreek en het voorkomen van eventuele gevestigde populaties is onderzocht aan de hand van literatuur. Daarnaast is contact gezocht met enkele onderzoeksgroepen in Duitsland. Wasberen komen inmiddels in grote delen van Duitsland voor en de populaties groeien snel. In de grensstreek met Nederland zijn de aantallen nog relatief laag, maar als de huidige populatietrends doorzetten, verandert dat naar verwachting op korte termijn. In Niedersachsen en Nordrhein-Westfalen - de deelstaten die aan Nederland grenzen - zijn de grootste populaties aanwezig in het oostelijk deel van deze deelstaten, circa 100-150 km vanaf de Nederlandse grens. Op basis van de aantallen geregistreerd afschot/valwild is de kans groot dat inmiddels, op een aantal plaatsen, gevestigde populaties dicht bij de Nederlandse landsgrens voorkomen. In Nederland is op basis van de ervaringen in de Duitse grensstreek een groeisnelheid van circa 12 tot $20 \%$ te verwachten na het ontstaan van gevestigde populaties.

Naar aanleiding van dit onderzoek doen wij de volgende aanbevelingen:

- Wij bevelen aan om de komende jaren het voorkomen van Wasberen in de grensstreek met Duitsland te monitoren. De verwachting is dat het aantal Wasberen in de grensstreek op niet al te lange termijn zal toenemen, gezien de snelle groei van de populaties in Duitsland en de snelle uitbreiding van hun areaal daar.

- Wij bevelen hetzelfde aan voor de grensstreek met België in Zuid-Limburg, omdat recentelijk ook het aantal waarnemingen in Wallonië toeneemt.

- Wij bevelen aan een helder plan van aanpak op te stellen voordat de Wasbeer zich definitief vestigt en binnen onze landsgrenzen één of meer populaties vormt. Geldt er een nulstandbeleid, accepteren we lage aantallen of laten we de soort geheel ongemoeid omdat elders bestrijding niet effectief is gebleken? 


\section{$1 \quad$ Inleiding}

\section{$1.1 \quad$ Achtergrond}

Momenteel komt de Wasbeer (Procyon lotor) incidenteel voor in Nederland (Lammertsma et al. 2008; Maas et al. 2012; Montizaan \& Hollander, 2015). De herkomst van de dieren is vaak onduidelijk. Meestal gaat het om verkeersslachtoffers, maar er zijn ook meldingen van levende dieren of pootafdrukken. Het betreft naar verwachting vooral dieren die zijn uitgezet of ontsnapt. Daarnaast bestaat de kans dat Wasberen ons land binnenkomen vanuit Duitsland of België. Er zijn momenteel nog geen bewijzen voor een gevestigde populatie binnen onze landsgrenzen. De vondst van meerdere (aangereden) dieren op korte afstand van elkaar binnen een relatief korte tijdsperiode kan hier echter wel op wijzen. Zo zijn er recent drie dode Wasberen gevonden nabij Doetinchem. Omdat Wasberen exoten zijn en daarbij een potentieel gevaar voor de volksgezondheid kunnen vormen door de parasieten die ze bij zich dragen, wil Bureau Risicobeoordeling en onderzoeksprogrammering (BuRO) van de Nederlandse Voedsel- en Warenautoriteit (NVWA) meer inzicht krijgen in de verspreiding en mogelijke vestiging van de Wasbeer in Nederland en de Duitse grensstreek.

\subsection{Doel van het onderzoek}

Het doel van het onderzoek is het voorkomen van de Wasbeer in Nederland en de Duitse grensstreek in beeld te brengen en te onderzoeken of er sprake is van gevestigde populaties. Een populatie wordt als 'gevestigd' aangemerkt als er lokaal succesvolle reproductie heeft plaatsgevonden.

De onderzoeksvragen zijn concreet:

1. Zijn in de periode 2009-2015 geregistreerde meldingen van Wasberen in Nederland gerelateerd aan lokaal gevestigde populaties?

2. Zijn wasberen aanwezig in het grensgebied met Duitsland, en gaat het hierbij om lokaal gevestigde populaties?

3. Komen er in de omgeving van de recente vindplaatsen bij Doetinchem meer Wasberen voor, en zo ja: is er sprake van een lokaal gevestigde populatie en hoe groot is het areaal van deze populatie?

\subsection{Werkwijze}

Dit onderzoek omvat zowel desk study als veldonderzoek. Om de eerste onderzoeksvraag te beantwoorden, is een verspreidingsbeeld voor de Wasbeer in Nederland vervaardigd voor de periode 2009-2015. Vervolgens is met behulp van enkele beslisregels geanalyseerd of er plekken zijn waar het voorkomen van een lokaal gevestigde populatie kansrijk is. De huidige verspreiding van de Wasbeer in de Duitse grensstreek en het voorkomen van eventuele gevestigde populaties is onderzocht aan de hand van literatuur. Daarnaast is contact gezocht met enkele onderzoeksgroepen in Duitsland. Er zijn veldinventarisaties uitgevoerd op twee plekken in Nederland die als kansrijk zijn aangemerkt voor het voorkomen van een lokaal gevestigde populatie: in de omgeving van Doetinchem en in de Dordtse Biesbosch. Hierbij is gebruikgemaakt van cameravallen, sporenonderzoek en buurtonderzoek. 


\section{Wasberen in Nederland}

\section{$2.1 \quad$ Inleiding}

In dit hoofdstuk richten we ons op de vraag of er binnen Nederland lokaal gevestigde populaties van Wasberen voorkomen. We beperken ons hierbij tot een analyse van de meldingen die in de laatste jaren zijn gedaan (2009-2015). De analyse is indicatief; kansrijke locaties voor een gevestigde populatie worden geïdentificeerd, maar zekerheid omtrent het al dan niet voorkomen van een populatie kan slechts worden verkregen door veldonderzoek ter plaatse.

\section{$2.2 \quad$ Methode}

In een eerste stap is een verspreidingsbeeld voor de Wasbeer in Nederland vervaardigd voor de periode 2009-2015 (peildatum: 1-1-2009 tot 1-7-2015). Voor dit verspreidingsbeeld zijn alle registraties uit deze periode van Wasberen in Nederland verzameld. Hierbij is gebruikgemaakt van drie bestaande gegevensbestanden: (1) Nationale Databank Flora en Fauna (NDFF, data opgevraagd juni 2015), inclusief het databestand van www.telmee.nl, (2) het databestand www.waarneming.nl en (3) het databestand van Stichting AAP. Daarnaast is naar nieuwsberichten op internet gezocht waarin melding wordt gemaakt van in Nederland waargenomen Wasberen en zijn enkele terreinbeheerders en veldbiologen benaderd om eventuele (nog) niet geregistreerde waarnemingen te achterhalen. De verzamelde waarnemingen zijn op een $5 * 5 \mathrm{~km}$-schaal op kaart weergegeven. Hierbij is aangegeven of de waarneming zeker of onzeker is. Deze kwalificaties zijn gebaseerd op de kwalificaties die de diverse databestanden geven aan de betrouwbaarheid van de waarnemingen. In het gegevensbestand van Stichting AAP ontbreekt deze informatie. Voor deze waarnemingen hebben wij de betrouwbaarheid geschat, waarbij als vuistregel is gehanteerd dat dood of levend binnengebrachte dieren 'zeker' zijn en overige meldingen van dieren 'onzeker' zijn. Uit het gegevensbestand van Stichting AAP zijn alleen waarnemingen van in het wild aangetroffen dieren en/of in het wild gevangen dieren meegenomen in het onderzoek. Ingeval er binnen een $5 * 5 \mathrm{~km}$-hok zowel zekere als onzekere waarnemingen liggen, dan is dit km-hok geclassificeerd als zeker.

In een tweede stap is met behulp van twee beslisregels geanalyseerd of er plekken zijn waar het voorkomen van een lokaal gevestigde populatie kansrijk is. Het betreft de volgende beslisregels:

1. Een plek waar in 2014 of de eerste helft van 2015 zowel adulte dieren als één of meer jonge dieren zijn waargenomen en deze waarneming(en) als zeker is (zijn) geclassificeerd.

2. Een plek met minimaal twee waarnemingen van adulte dieren die (1) maximaal $4800 \mathrm{~m}$ van elkaar liggen, (2) binnen 12 maanden van elkaar zijn gedaan en (3) waarvan minimaal één waarneming in 2014 of in de eerste helft van 2015 is gedaan.

De in de eerste beslisregel gehanteerde voorwaarde dat naast jonge dieren ook adulte dieren moeten zijn waargenomen, is om te voorkomen dat ontsnapte/vrijgelaten jonge dieren worden geïnterpreteerd als gevestigde populatie. Als de waarnemingen conform de eerste beslisregel ouder zijn dan 18 maanden, achten we de kans op een gevestigde populatie nihil.

De in de tweede beslisregel gehanteerde maximale afstand (4800 m) sluit aan bij methoden om invasieve soorten te controleren (Smith et al. 2015) en is gerelateerd aan de (gemiddelde) homerange-grootte van mannelijke dieren in sub-urbaan en urbaan gebied, die circa 200-250 ha is (zie kader Homerange Wasbeer). Projecteren we deze homerange-grootte in een cirkelvorm rond de vindplaatsen, dan reikt de homerange tot circa $800 \mathrm{~m}$ van de vindplek. Een dier kan echter aan de rand van zijn homerange zijn waargenomen en homeranges zijn nooit precies cirkelvormig. Om deze onzekerheden te ondervangen, gebruiken we hier daarom rond iedere vindplek een cirkelvormige buffer met een straal van $3^{*} 800=2400 \mathrm{~m}$. In de analyse van gevestigde populaties hanteren we hier 
als maximale afstand tussen twee waarnemingen tweemaal die afstand. De buffers van twee naburige vindplekken moeten dus precies aan elkaar grenzen of elkaar (deels) overlappen. Deze beslisregel impliceert dat dieren die op grotere afstand van elkaar zijn waargenomen, geen gevestigde populatie indiceren.

Wij nemen aan dat ingeval er op een plek sprake is van een gevestigde populatie er met enige regelmaat Wasberen zullen worden waargenomen. Wij gebruiken hier een relatief ruime maat van 12 maanden als maximale tijd tussen twee waarnemingen, omdat we rekening willen houden met eventueel schuw gedrag en/of een verborgen levenswijze van de dieren. Als er op een plek in de laatste 18 maanden geen waarnemingen conform de tweede beslisregel van Wasberen zijn gedaan, achten we de kans op een gevestigde populatie nihil.

Homerange Wasbeer

Er zijn geen gegevens over de homerange-grootte van Wasberen in Nederland. In Duitsland, Polen en Luxemburg is wel enig onderzoek gedaan. De homerange-groottes blijken zeer variabel en zijn nauw gerelateerd aan het geslacht van het dier en het habitattype. Homeranges van mannen zijn meestal enkele malen groter dan die van vrouwen. Homeranges in (sub)urbaan gebied zijn veel beperkter in omvang dan homeranges in moeras- of bosgebieden. Ook zijn er verschillen tussen de seizoenen. Bijlage 1 vat de resultaten van het bestaande onderzoek naar homeranges van Wasberen in Europa samen.

In Nederland zijn veel waarnemingen van Wasberen gedaan in (sub)urbaan en agrarisch gebied. Waarnemingen binnen grote bos- of moerasgebieden zijn relatief zeldzaam. Voor het schatten van een (gemiddelde) homerange-grootte voor Wasberen in Nederland baseren we ons hier daarom op de studies van Bartoszewicz et al. (2008) en Michler (2003), waarin de homeranges van Wasberen in sub-urbaan en urbaan gebied zijn bepaald. De homerange-grootte van mannelijke dieren in deze studies was gemiddeld respectievelijk 210 en 235 ha. We ronden dit getal hier voor gebruik in de analyse af naar 200 ha.

\subsection{Resultat}

\subsubsection{Verspreiding in Nederland}

In de periode 1-1-2009 tot 1-7-2015 zijn in Nederland 90 waarnemingen van een Wasbeer geregistreerd (figuur 2.1). Hiervan zijn er 60 geclassificeerd als zeker en 30 als onzeker. De leeftijdsklasse is voor 46 waarnemingen geregistreerd: 40 adulte dieren, 6 jonge dieren (figuur 2.2). Het geslacht van de dieren is voor 18 waarnemingen geregistreerd: 6 vrouwen, 12 mannen (figuur 2.3). De meeste waarnemingen betreffen zichtwaarnemingen (figuur 2.4). Hiervan is echter circa de helft geclassificeerd als onzeker. Waarnemingen die met cameravallen zijn gedaan en gevangen of dood gevonden Wasberen betreffen, zijn vaker als zeker geclassificeerd. Het aantal waarnemingen op basis van sporen is beperkt en deze zijn meestal onzeker.

De aantallen variëren sterk per jaar. In 2011 zijn de minste waarnemingen gedaan $(n=5)$ en in 2014 de meeste $(n=22)$. Er zijn geen duidelijke aanwijzingen voor een stijgende trend: gemiddeld zijn 12-13 waarnemingen per jaar gedaan in de periode 2009-2011 en 14-15 waarnemingen per jaar in de periode 2012-2015. Het beeld is voor de tweede periode echter enigszins vertekend, omdat deze een relatief groot aantal waarnemingen (van mogelijk slechts één of enkele individuen) in de Biesbosch omvat die in 2014 en 2015 met cameravallen zijn gedaan. Het verspreidingsbeeld - met waarnemingen verspreid over nagenoeg het hele land - suggereert dat de meeste waarnemingen ontsnapte of losgelaten huisdieren betreffen. Dit kan ook de sterke variatie tussen jaren verklaren, want als de waarnemingen vooral een gevolg zijn van een gestage instroom van Wasberen vanuit de bestaande populaties in Duitsland, zijn minder variatie en een duidelijke stijgende trend te verwachten. 
Ook na de in dit onderzoek gehanteerde onderzoeksperiode zijn er Wasberen waargenomen in Nederland. Hoewel deze waarnemingen niet in de analyses zijn betrokken, geven we hier voor de volledigheid wel een overzicht (zie bijlage 2). Opmerkelijk in dit overzicht zijn vier meldingen binnen 12 maanden in Zuid-Limburg. Dit is mogelijk gerelateerd aan groeiende aantallen in Wallonië (zie bijlage 3).

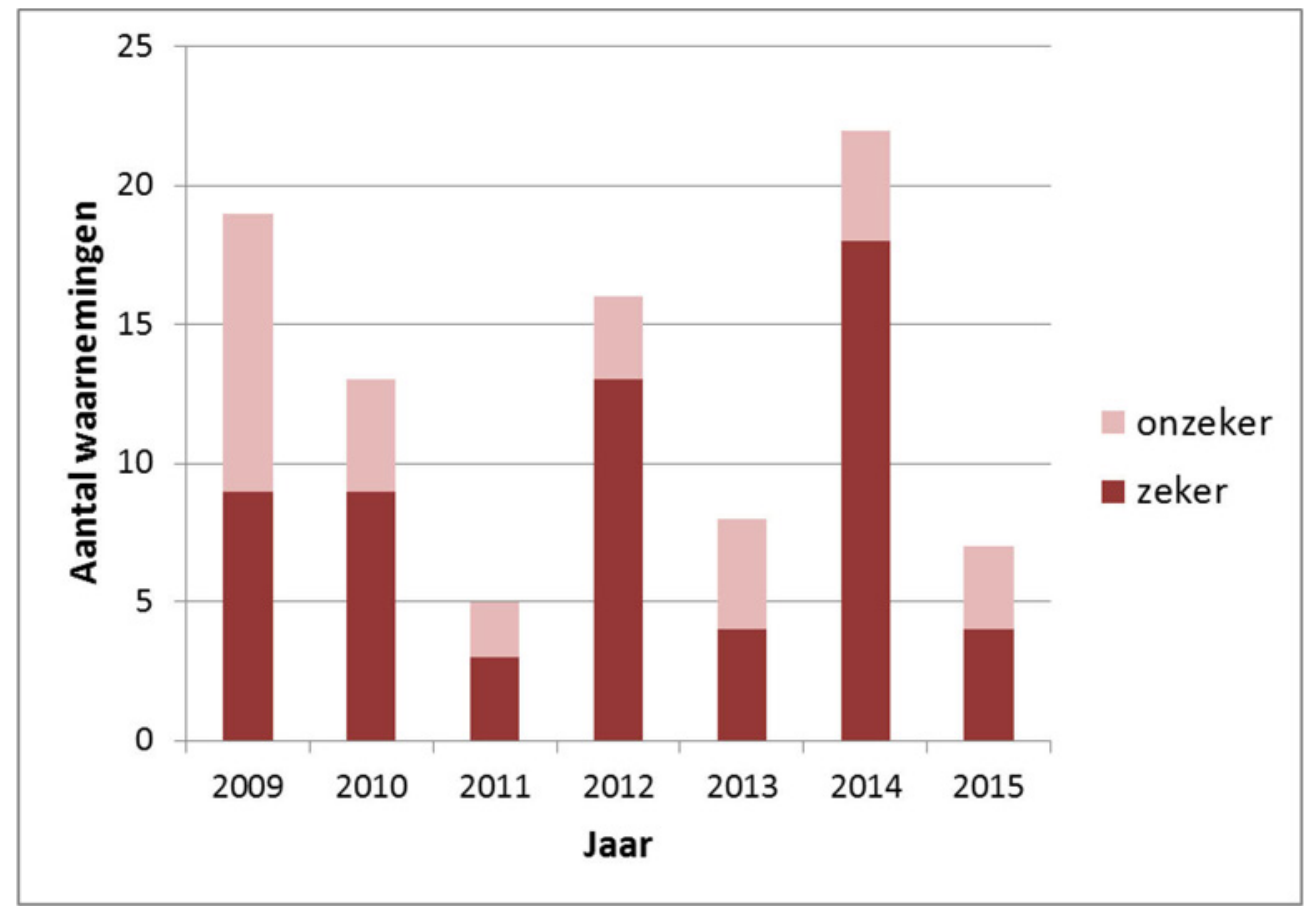

Figuur 2.1 Het aantal zekere en onzekere waarnemingen van Wasberen in Nederland in de periode 1-1-2009 tot 1-7-2015.

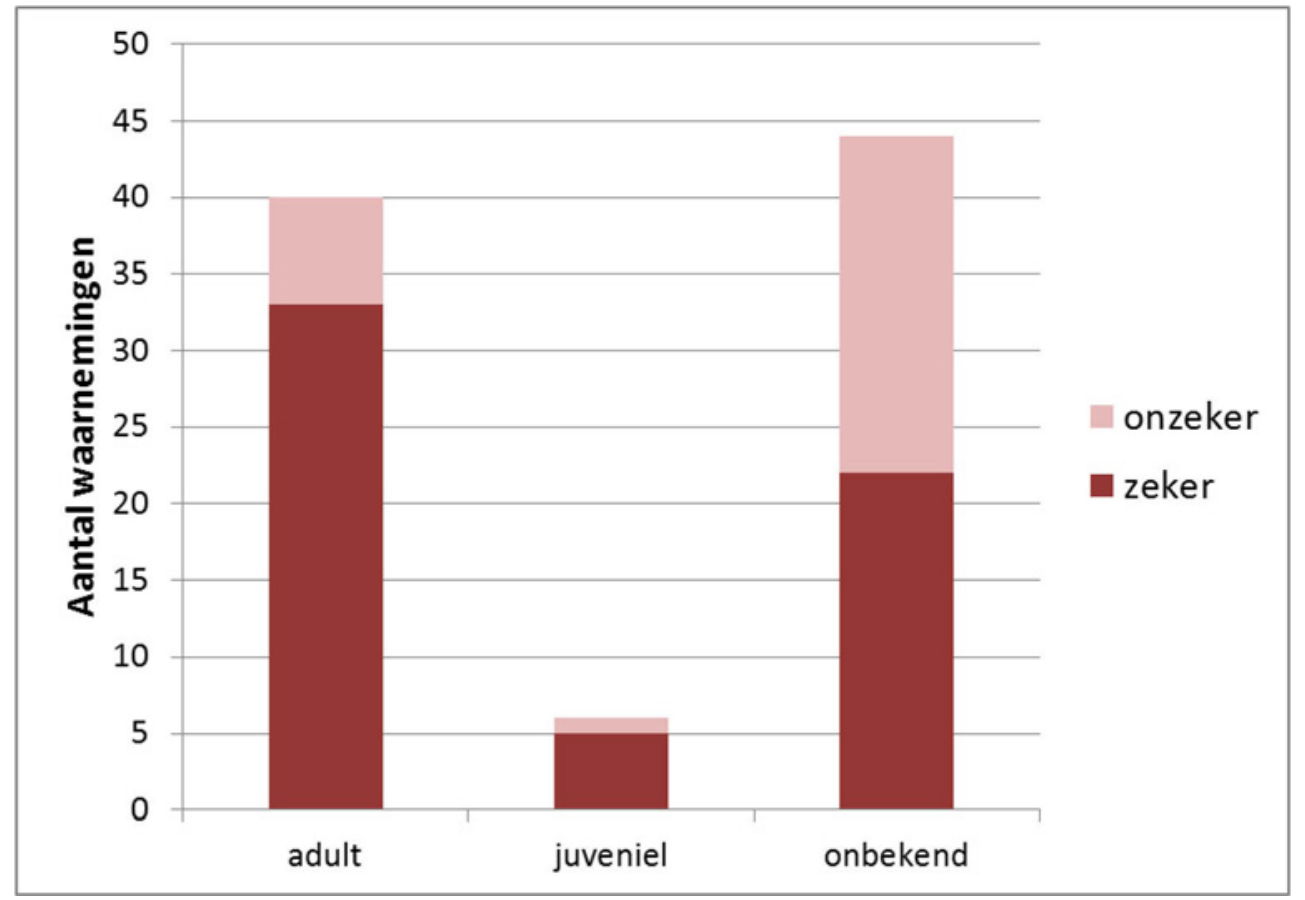

Figuur 2.2 Het aantal zekere en onzekere waarnemingen van Wasberen in Nederland per leeftijdsgroep in de periode 1-1-2009 tot 1-7-2015. 


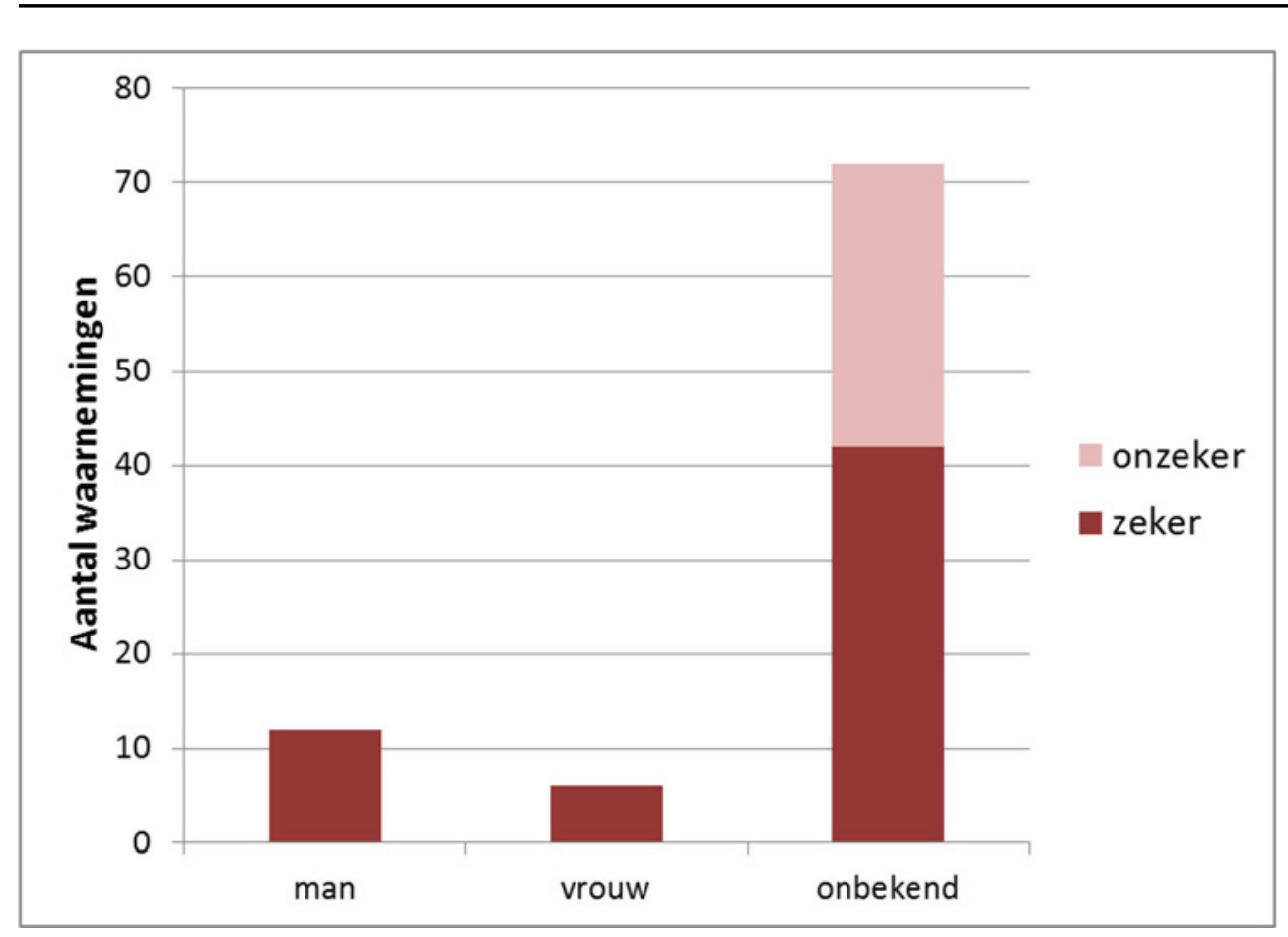

Figuur 2.3 Het aantal zekere en onzekere waarnemingen van Wasberen in Nederland per geslacht in de periode 1-1-2009 tot 1-7-2015.

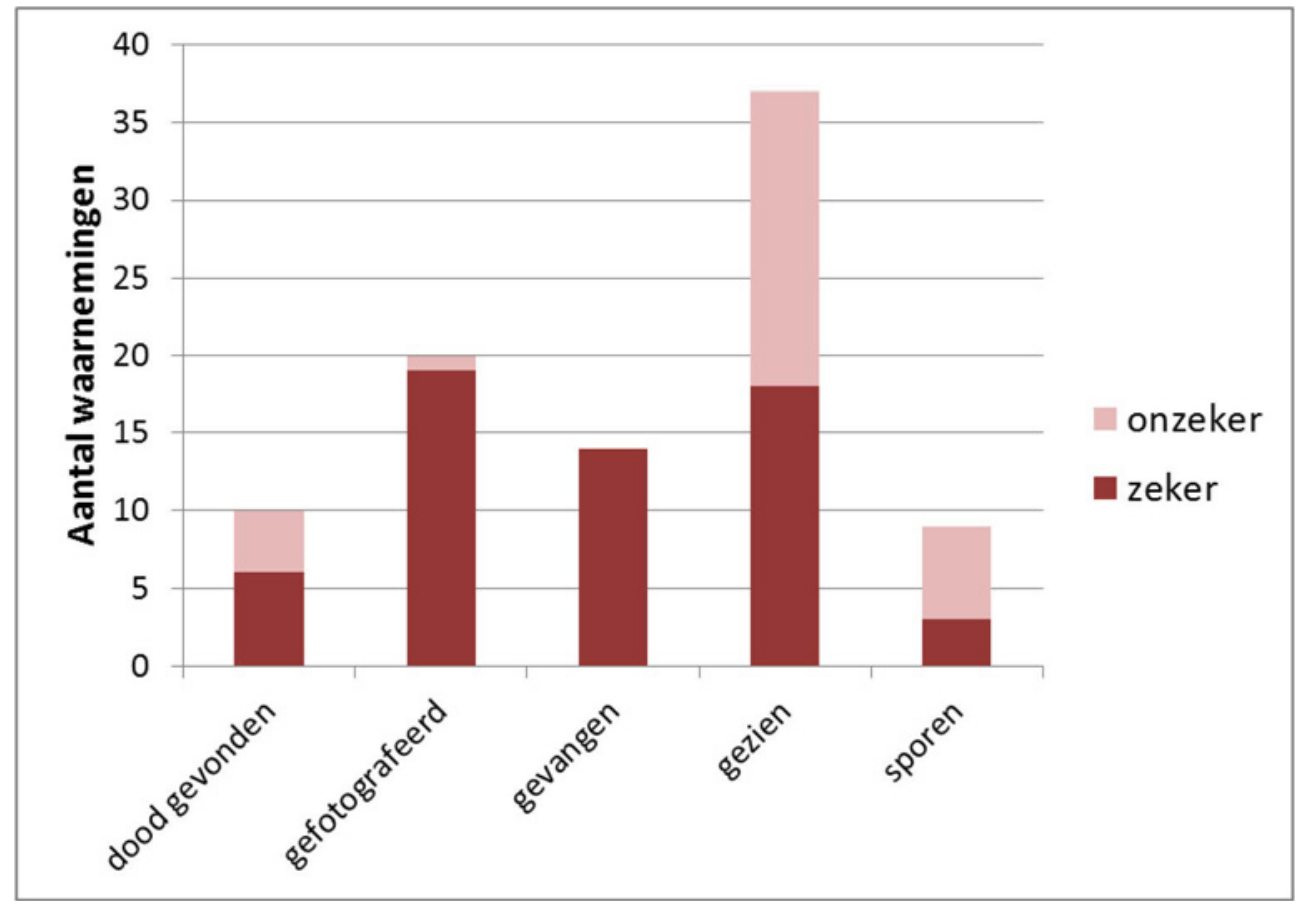

Figuur 2.4 Het aantal zekere en onzekere waarnemingen van Wasberen in Nederland per detectiemethode in de periode 1-1-2009 tot 1-7-2015. 
Figuur 2.5 geeft een overzicht van de vindplekken van Wasberen in Nederland in de periode 20092015. Zes geregistreerde waarnemingen zijn niet in de kaart verwerkt, omdat de vindplek van de dieren te globaal is aangegeven $(n=2)$ of niet openbaar is $(n=4)^{1}$. De nauwkeurigheid waarmee de vindplekken in de diverse databestanden zijn geregistreerd, varieert sterk: GPS-coördinaten $(n=41)$, km-hokaanduiding $(n=11)$, indicatieve aanduiding van een plaats of gebied $(n=34)$. Waarnemingen van Wasberen zijn gedurende de onderzoeksperiode gedaan in alle provincies, behalve Zeeland (figuur 2.6). De meest waarnemingen zijn gedaan in Zuid-Holland. Dit is vooral een gevolg van het relatief grote aantal waarnemingen in het Hollandse deel van de Biesbosch. Relatief weinig waarnemingen zijn gedaan in de provincies Friesland, Groningen, Drenthe en Flevoland. De soort is niet waargenomen op de Waddeneilanden.

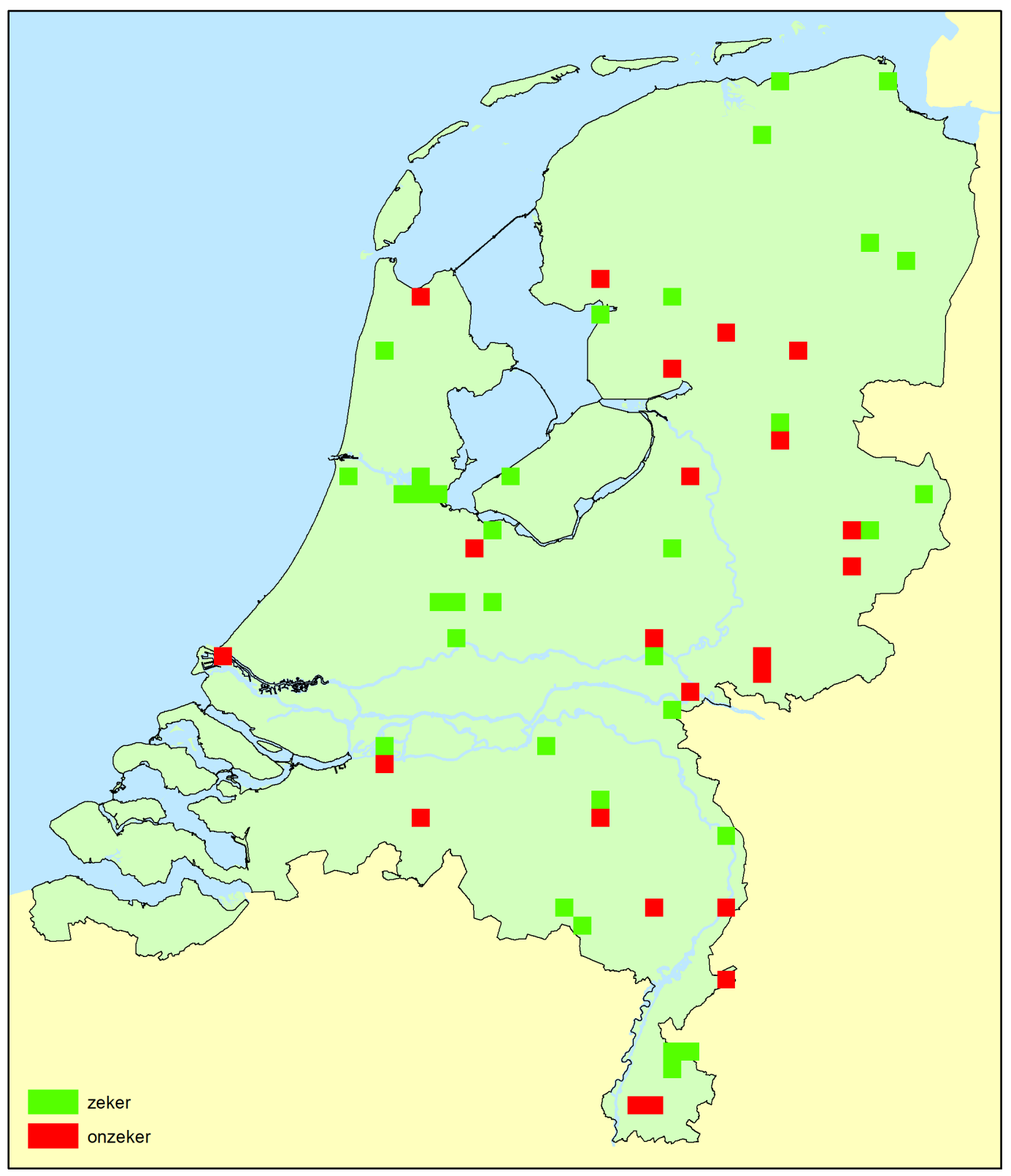

Figuur 2.5 Verspreiding van de Wasbeer in Nederland in de periode 1-1-2009 tot 1-7-2015.

\footnotetext{
${ }^{1}$ In het gegevensbestand van de website waarneming.nl kunnen waarnemers bepalen of hun waarnemingen voor iedereen toegankelijk zijn of dat een deel van de informatie - bijvoorbeeld de precieze vindplaats - wordt afgeschermd.
} 


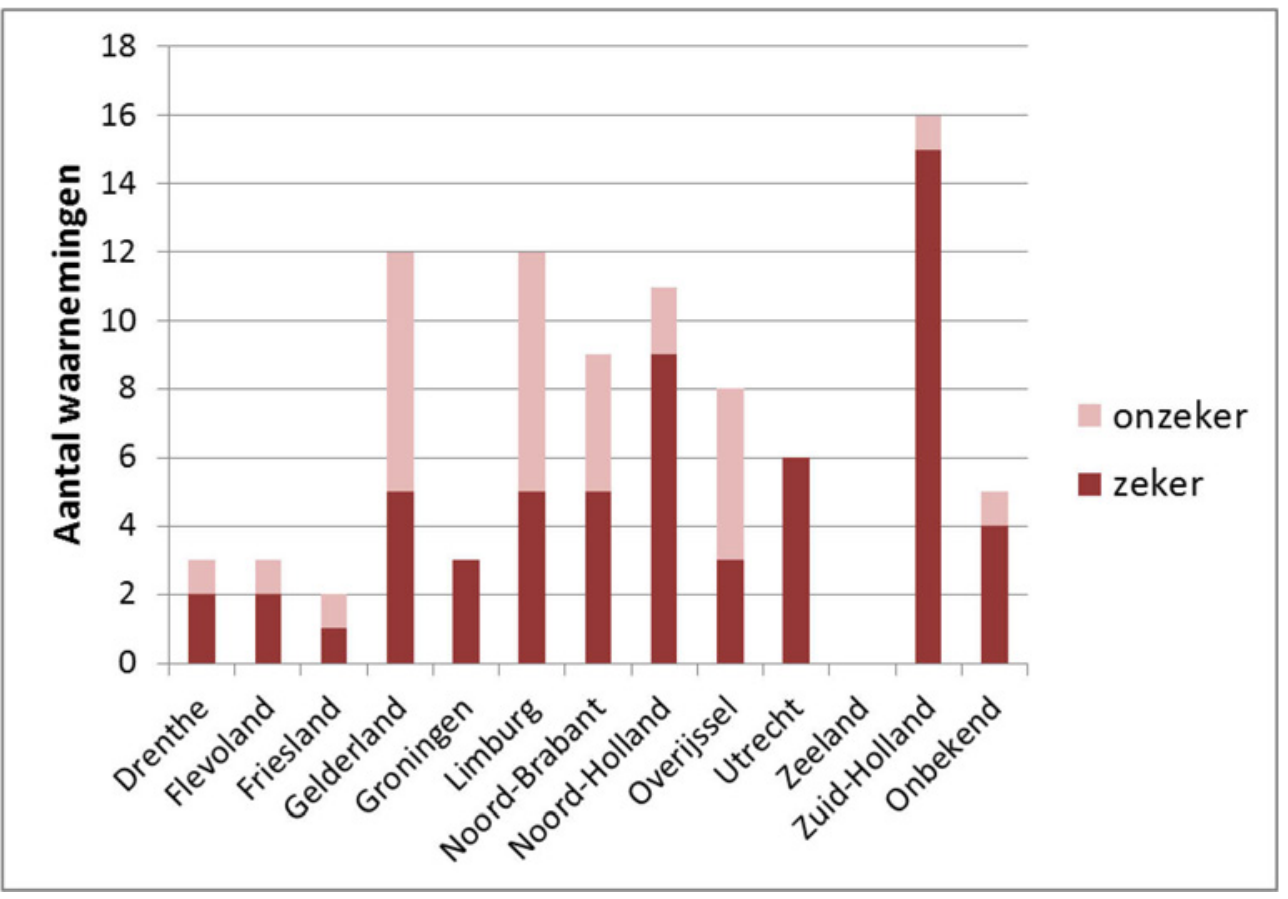

Figuur 2.6 Het aantal geregistreerde waarnemingen van Wasberen per provincie in de periode 1-1-2009 tot 1-7-2015.

\subsubsection{Kansrijke locaties voor lokaal gevestigde populaties}

Op basis van de eerste beslisregel is er één plek aan te wijzen die voldoet: Doetinchem. In totaal zijn er in de onderzoeksperiode zes jonge dieren geregistreerd. Vijf daarvan dateren echter uit de jaren 2009 ( $n=1$; zeker), 2010 ( $n=1$; onzeker) en 2013 ( $n=3$; zeker) en voldoen hiermee niet aan de eerste beslisregel. In de omgeving van Doetinchem is een aangereden jong dier gevonden (vrouw) in oktober 2014. Daarnaast zijn hier enkele registraties van adulte dieren gedaan in dezelfde periode.

Op basis van de tweede beslisregel zijn er twee plekken aan te wijzen die voldoen: (1) Doetinchem, en (2) Biesbosch. In de omgeving van Doetinchem zijn in de onderzoeksperiode zes waarnemingen van Wasberen geregistreerd. Het betreft een waarneming van drie adulte dieren in een tuin aan de Oude Terborgseweg in 2009 en de vondst van drie verkeersslachtoffers in 2014. De verkeersslachtoffers zijn gevonden op respectievelijk de Oude Terborgseweg (man), Gaanderense weg (geslacht onbekend) en Rekhemseweg (vrouw). Deze vindplaatsen liggen op korte afstand van elkaar.

In 2014 en 2015 zijn door de Natuur- en Vogelwacht Biesbosch regelmatig Wasberen waargenomen met behulp van cameravallen in de Dordtse Biesbosch (figuur 2.7). In de periode 2009-2015 is de eerste waarneming gedaan in april 2014 en de laatste waarneming in juli 2015. Het is onzeker of het hier om één of meerdere individuen gaat. Eenmaal kon aan de hand van de foto's het geslacht worden vastgesteld. Dit betrof een mannelijk dier. Dit mannelijke dier is meerdere keren waargenomen, wat kon worden vastgesteld op basis van zijn unieke staarttekening (J. Mulder, pers. communicatie; zie ook Zeveloff 2002). 


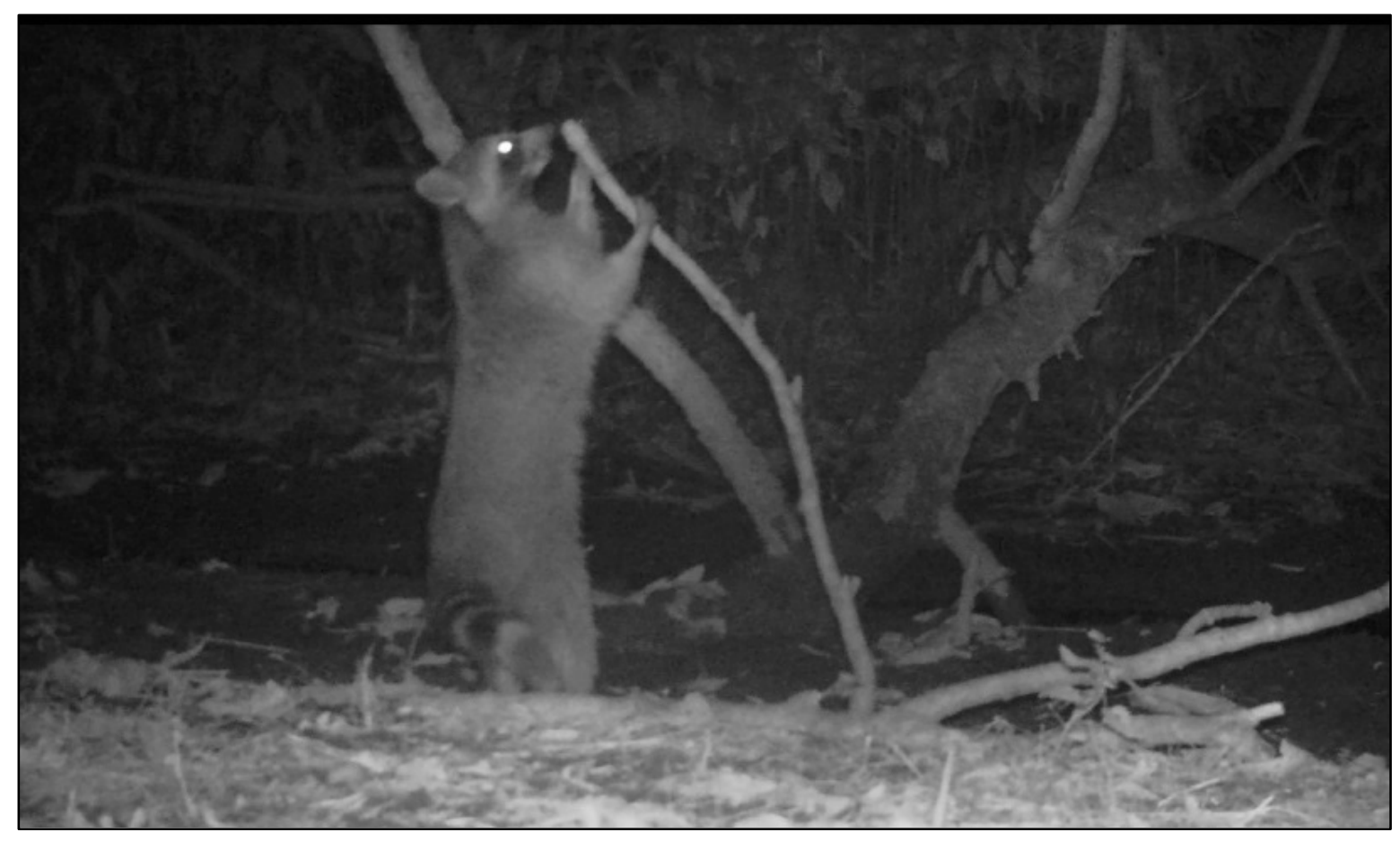

Figuur 2.7 Een Wasbeer gefotografeerd in de Dordtse Biesbosch, mei 2015 (Bron: Rob Haan, NWC/Natuur- en Vogelwacht Biesbosch).

\subsection{Conclusies}

- In de periode 2009-2015 zijn er regelmatig Wasberen gezien in Nederland. De waarnemingen komen uit nagenoeg alle delen van het land, met uitzondering van Zeeland en de Waddeneilanden. Er is geen duidelijke trend - positief of negatief - te zien in de geregistreerde aantallen tussen 2009 en 2015.

- Op basis van de geregistreerde meldingen van Wasberen in Nederland in de periode 2009-2015 zijn er twee locaties aan te wijzen die kansrijk zijn voor een lokaal gevestigde populatie. Dit betreft de omgeving van Doetinchem en de Dordtse Biesbosch. 


\section{Wasberen in de Duitse grensstreek}

\section{$3.1 \quad$ Inleiding}

In dit hoofdstuk richten we ons op de vraag of er in de Duitse grensstreek lokaal gevestigde populaties van Wasberen voorkomen. Gevestigde populaties in de grensstreek kunnen immers betekenen dat meer Wasberen vanuit Duitsland ons land bereiken en hier populaties gaan vormen. De aandacht gaat vooral uit naar de aan Nederland grenzende deelstaten, Niedersachsen en Nordrhein-Westfalen.

\section{$3.2 \quad$ Methode}

$\mathrm{Er}$ is geen databestand beschikbaar waarin alle Duitse waarnemingen - d.w.z. zichtwaarnemingen, verkeersslachtoffers, afschot etc. - van Wasberen zijn geregistreerd. Wel zijn er rapportages die de verspreiding van de soort (globaal) beschrijven en er zijn afschot- en valwildgegevens ${ }^{2}$ beschikbaar op deelstaatniveau. De huidige verspreiding van de Wasbeer in de Duitse grensstreek en het voorkomen van eventuele gevestigde populaties is daarom primair onderzocht aan de hand van literatuur. Hierbij is gebruikgemaakt van Science Direct en Google Scholar, met als zoekopdracht "Procyon lotor" OF "raccoon" OF "waschbär" EN "distribution" OF "verbreitungsgebiet" OF "verbreitung" OF "ausbreitung". De referentielijsten in de op deze wijze gevonden publicaties zijn gecheckt voor eventuele aanvullende publicaties. Daarnaast is contact gezocht met enkele onderzoeksgroepen in Duitsland (zie bijlage 4) en is gebruikgemaakt van rapporten en artikelen in eigen bezit.

\subsection{Resultaat}

\subsubsection{Verspreiding in Duitsland}

De Wasbeer komt momenteel in grote delen van Duitsland voor. De soort is geïntroduceerd door vrijlatingen en ontsnappingen uit een fokkerij in de jaren dertig en veertig van de vorige eeuw (Fischer et al. 2015). In de decennia daarna nam het aantal in het wild levende Wasberen toe. Pogingen om de soort uit te roeien, mislukten. Momenteel zijn er gevestigde populaties in de meeste deelstaten, inclusief de aan Nederland grenzende deelstaten Nordrhein-Westfalen en Niedersachsen. Gedetailleerde wetenschappelijke studies naar de populatiedynamiek van Wasberen, groeisnelheden en de factoren en processen die hierop van invloed zijn, zijn tot op heden nauwelijks voorhanden (Troyer et al. 2014). Globaal kan op basis van de registraties van afschot en valwild in Duitsland wel een indruk worden verkregen van de snelheid waarmee Wasbeerpopulaties kunnen toenemen (zie bijlage 5). De populaties in Duitsland ontwikkelen zich de laatste jaren explosief, zowel wat betreft verspreiding als aantallen. Figuur 3.1 illustreert dit aan de hand van de aantallen afgeschoten dieren en valwild in de periode 2004-2014. In tien jaar tijd zijn deze aantallen vervijfvoudigd van circa 20.000 in 2004 tot circa 100.000 in 2014. Wanneer deze registraties gezien worden als indicator voor de populatiegrootte, dan groeit de populatie daarmee gemiddeld $17 \%$ per jaar.

\footnotetext{
${ }^{2}$ Valwild kan worden gedefinieerd als dieren die op een andere manier zijn doodgegaan dan door jacht, bijvoorbeeld dieren die verkeersslachtoffer zijn geworden.
} 


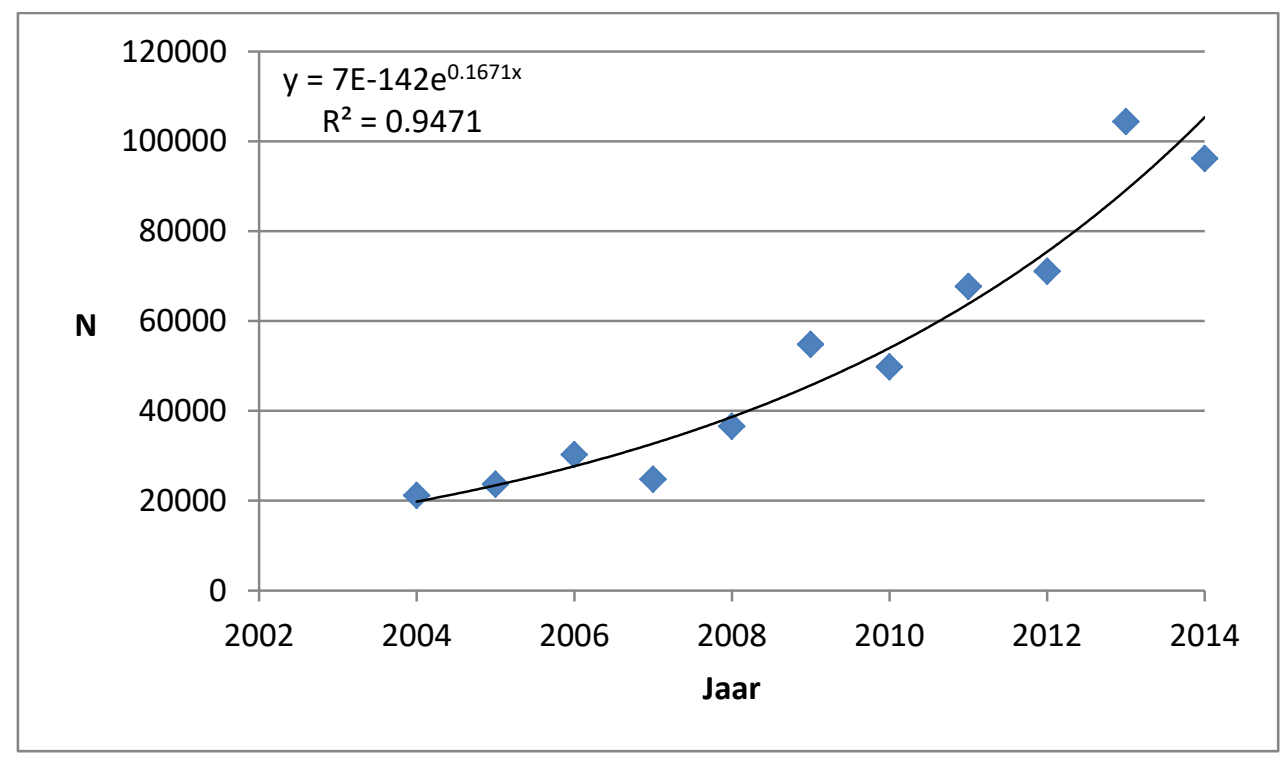

Figuur 3.1 Aantal dode Wasberen (afschot en valwild samen) in Duitsland in de periode 2004-2014 (bron: Deutscher Jagdverband, Handbuch 2015; www.jagdverband.de).

\subsubsection{Populaties in Niedersachsen}

In Niedersachsen is, net als in de andere deelstaten, sprake van een explosieve populatiegroei. Het aantal afgeschoten dieren en valwild steeg van circa 1.400 in 2004 tot circa 8.400 in 2014 (figuur 3.2). Wanneer deze registraties gezien worden als indicator voor de populatiegrootte, dan groeit de populatie daarmee gemiddeld $20 \%$ per jaar.

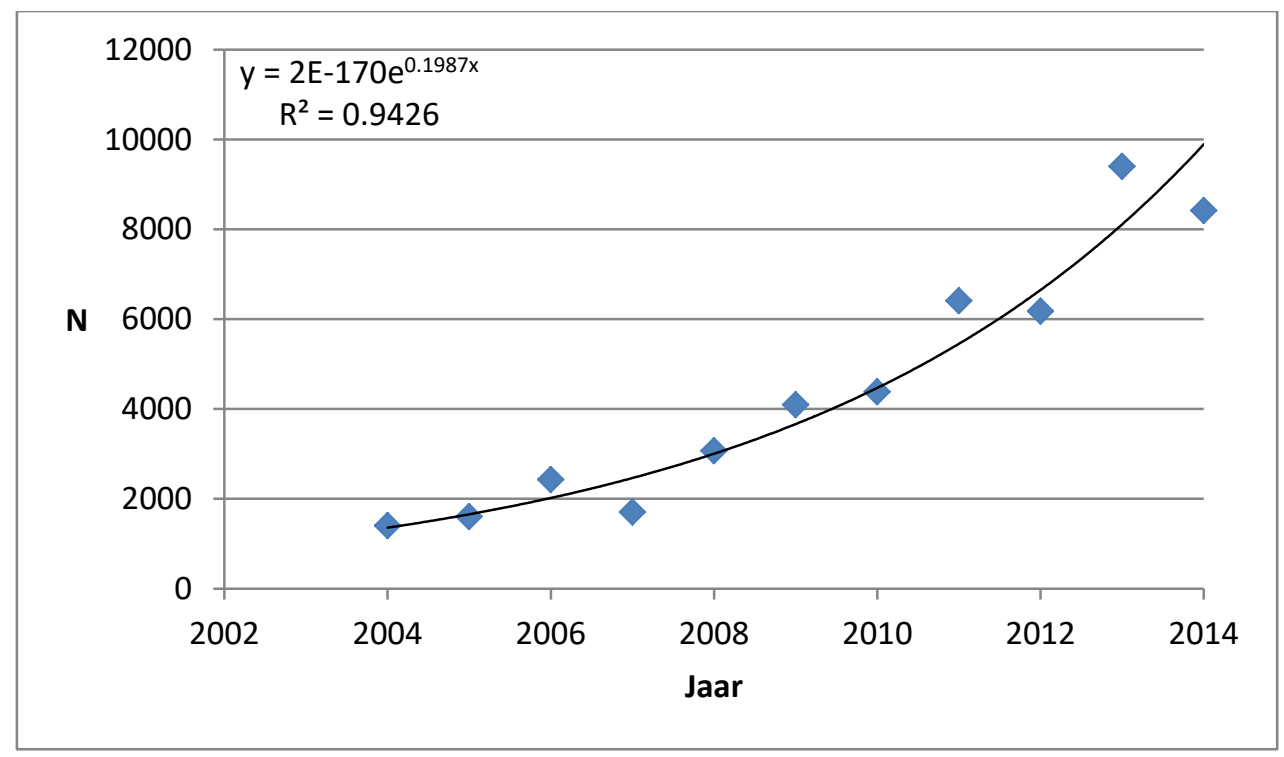

Figuur 3.2 Aantal dode Wasberen (afschot en valwild samen) in Niedersachsen in de periode 20042014 (bron: Deutscher Jagdverband, Handbuch 2015; www.jagdverband.de).

De grootste aantallen leven in het oosten van deze deelstaat (figuur 3.3). Circa 50\% van de 8.414 Wasberen die in 2013-2014 in Niedersachsen zijn geschoten komen uit drie landeskreisen in het oosten van de deelstaat. De soort is nog niet aangetroffen op de Duitse Waddeneilanden (landeskreisen Aurich, Friesland, Leer, Wittmund; Gräber et al. 2014). De aantallen in de direct aan Nederland grenzende landeskreisen zijn op dit moment nog relatief laag. In 2013-2014 zijn binnen de hier gelegen gemeenten ('gemeinden') geen dieren, 1 tot 20 dieren of 21-40 dieren geschoten of geregistreerd als valwild. 


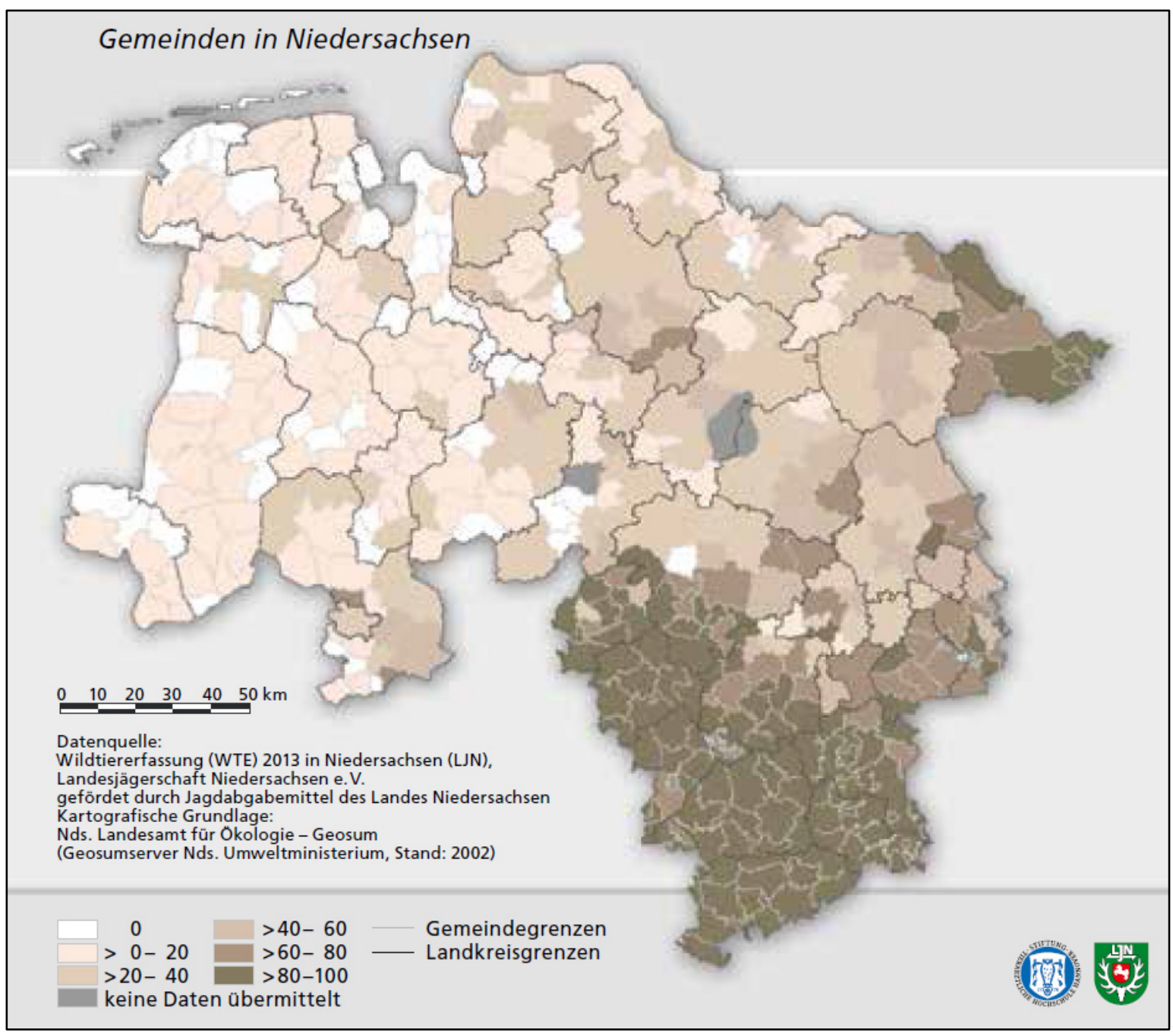

Figuur 3.3 Ruimtelijke spreiding van het aantal dode Wasberen (afschot en valwild samen) in Niedersachsen in 2013-2014 (bron: Gräber et al. 2014).

\subsubsection{Populaties in Nordrhein-Westfalen}

In Nordrhein-Westfalen is, net als in de andere deelstaten, sprake van een explosieve populatiegroei. Het aantal afgeschoten dieren en valwild steeg van circa 3.100 in 2004 tot circa 8.700 in 2014 (figuur 3.4). Wanneer deze registraties gezien worden als indicator voor de populatiegrootte, dan groeit de populatie daarmee gemiddeld $12 \%$ per jaar.

Ook in Nordrhein-Westfalen leven de grootste aantallen in het oosten van de deelstaat (figuur 3.5). De aantallen in de direct aan Nederland grenzende landeskreisen zijn op dit moment nog relatief laag. In 2013-2014 zijn binnen hier geen, 1-2, 5-10 of 20-40 dieren geschoten of geregistreerd als valwild. De nieuwe jachtwet van Nordrhein-Westfalen leidt naar verwachting tot een daling in het aantal bejaagde Wasberen omdat veelgebruikte jachtmethoden - het uitzetten van vallen en jacht met honden in vossen- en dassenburchten - niet langer worden toegestaan (W. Lutz, pers. commentaar). De eerste reactie van een jager - die al vele jaren de jacht op Wasberen in de grensstreek met Nederland organiseert - was: "We hebben voortdurend 60 tot 90 Wasberen per jaar geschoten. Nu stoppen we met die jacht." De verwachting is dat meer jagers dit besluit nemen. Hierdoor kunnen populaties sneller groeien en zal het aantal dieren op dispersie de komende jaren toenemen. 


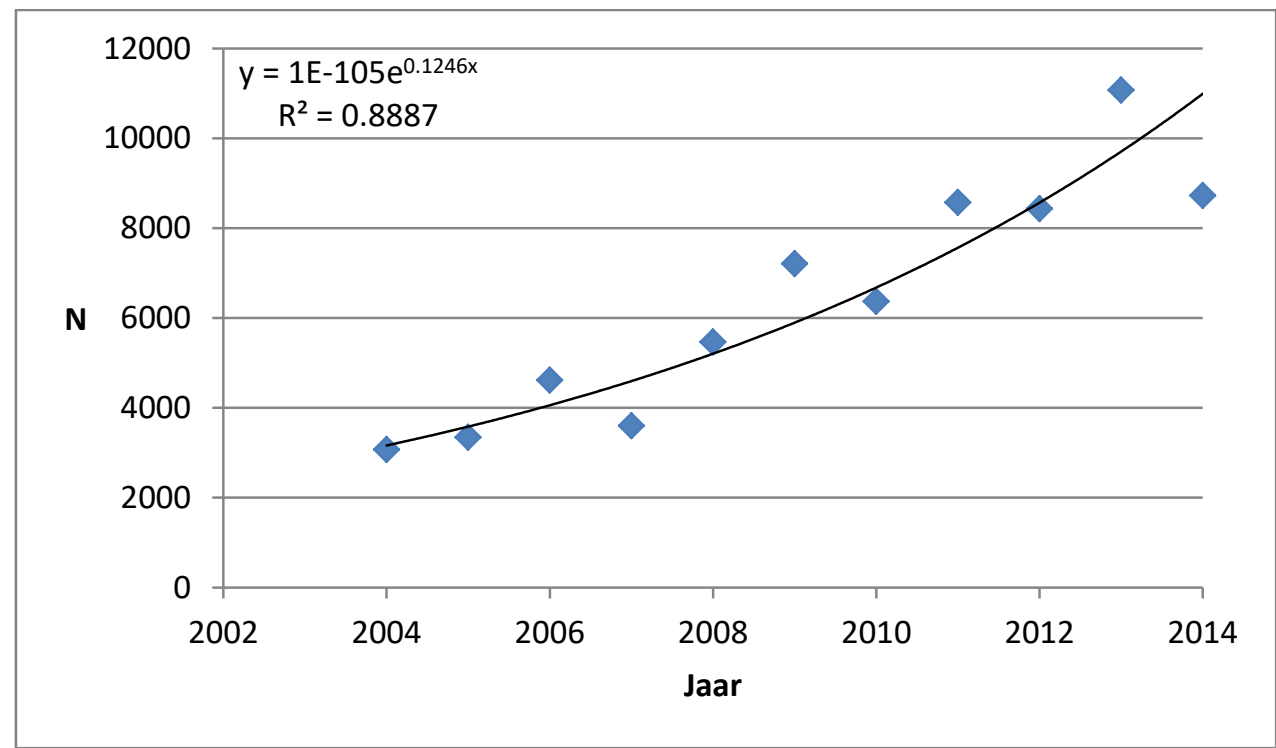

Figuur 3.4 Aantal dode Wasberen (afschot en valwild samen) in Nordrhein-Westfalen in de periode 2004-2014 (bron: Deutscher Jagdverband, Handbuch 2015; www.jagdverband.de).

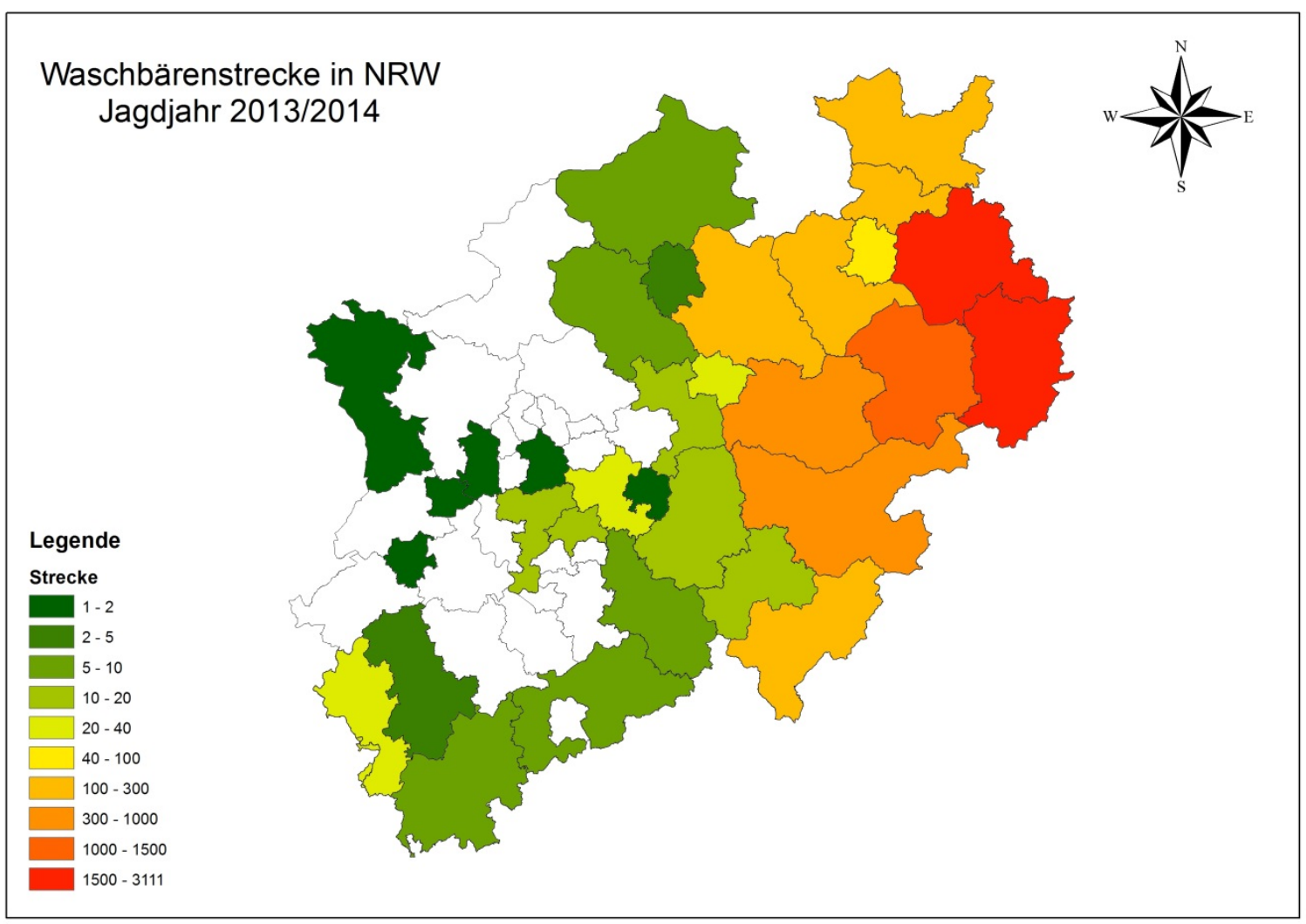

Figuur 3.5 Ruimtelijke spreiding van het aantal dode Wasberen (afschot en valwild samen) in Nordrhein-Westfalen in 2013-2014 (bron: Forschungsstelle für Jagdkunde und Wildschadenverhütung, Bonn). 


\subsection{Conclusies}

- Wasberen komen inmiddels in grote delen van Duitsland voor en de populaties groeien snel. In de grensstreek met Nederland zijn de aantallen nog relatief laag, maar als de huidige populatietrends doorzetten, verandert dat naar verwachting op korte termijn.

- In Niedersachsen en Nordrhein-Westfalen - de deelstaten die aan Nederland grenzen - zijn de grootste populaties aanwezig in het oostelijk deel van deze deelstaten, circa $100-150 \mathrm{~km}$ vanaf de Nederlandse grens.

- Op basis van de aantallen geregistreerd afschot/valwild is de kans groot dat inmiddels, op een aantal plaatsen, gevestigde populaties dicht bij de Nederlandse landsgrens voorkomen.

- In Nederland is op basis van de ervaringen in de Duitse grensstreek een groeisnelheid van circa 12 tot $20 \%$ te verwachten na het ontstaan van gevestigde populaties. 


\section{$4 \quad$ Veldinventarisatie Doetinchem}

\subsection{Inleiding}

In dit hoofdstuk richten we ons op de vraag of er in de omgeving van de vindplaatsen van de drie recent dood gevonden Wasberen nabij Doetinchem meer Wasberen voorkomen en zo ja, of hier sprake is van een lokaal gevestigde populatie. De dode Wasberen zijn alle aan de zuid-zuidoostkant van Doetinchem gevonden, op relatief korte afstand van elkaar. De afstand tussen de vindplek op de Rekhemseweg en de vindplek op de Oude Terborgseweg is circa 1,5 km. De afstand tussen de vindplek op de Oude Terborgseweg en de vindplek op de Gaanderenseweg is circa 0,8 km. De waarnemingen op de Rekhemseweg en de Oude Terborgseweg liggen (net) ten noorden van rijksweg A18. De waarneming op de Gaanderenseweg ligt (net) ten zuiden van de A18. Deze rijksweg wordt mogelijk dus door Wasberen gepasseerd.

\subsection{Methode}

Het voorkomen van Wasberen nabij Doetinchem is onderzocht met behulp van (1) infraroodcameravallen, (2) sporenonderzoek en (3) buurtonderzoek. Deze onderzoekstechnieken zijn tevens gebruikt om, als de Wasbeer nog voorkomt rond Doetinchem, vast te stellen of er reproductie plaatsvindt en wat het areaal is van de soort.

\subsubsection{Afbakening studiegebied}

Het studiegebied bestaat uit de gebieden binnen een straal van 2,4 km rond de drie plekken waar recent een dode Wasbeer is gevonden (figuur 4.1). Deze straal is gerelateerd aan de (gemiddelde) homerange-grootte van mannelijke Wasberen, die circa 200 ha is. Projecteren we deze homerangegrootte in een cirkelvorm rond de vindplaatsen, dan reikt de homerange tot circa $800 \mathrm{~m}$ van de vindplek. Als afbakening voor het studiegebied is hier driemaal die afstand gehanteerd, omdat een vindplek aan de rand van de homerange kan liggen en homeranges nooit precies cirkelvormig zijn (zie ook paragraaf 2.2).

\subsubsection{Infrarood-cameravallen}

In de periode 2 juli-9 september 2015 zijn binnen het studiegebied op 22 kansrijke locaties cameravallen (merk: ACORN en KÖNIG) met infrarooddetectie geplaatst (figuur 4.2), gebaseerd op de habitatvoorkeuren van de Wasbeer (zie kader Habitat Wasbeer). We gebruikten hierbij lokaas (kattenvoer) om de kans op detectie te vergroten. Het totaal aantal valnachten was 777. Het gemiddeld aantal valnachten per camera-locatie was 35. Bijlage 6 geeft een overzicht van de periode en het aantal valnachten per camera-locatie (figuur 4.3).

\section{Habitat Wasbeer}

Wasberen hebben een voorkeur voor waterrijk loofbos (moeras- en ooibossen). Droger (naald)bos en open gebieden worden meestal gemeden (Hermes et al. 2011), behalve wanneer er een piek in het voedselaanbod is. Wanneer bijvoorbeeld de mais rijp is, wordt daar intensief gebruik van gemaakt. Voor voortplanting en slaapplaatsen zijn Wasberen aangewezen op holen van Vos, Konijn en Das, maar ook holle bomen (oud bos) en gebouwen worden benut. Soms verblijven ze overdag ook in dichte vegetatie. De Wasbeer is een cultuurvolger die profiteert van menselijke aanwezigheid en de afwezigheid van grote predatoren (Ingle et al. 2014). 


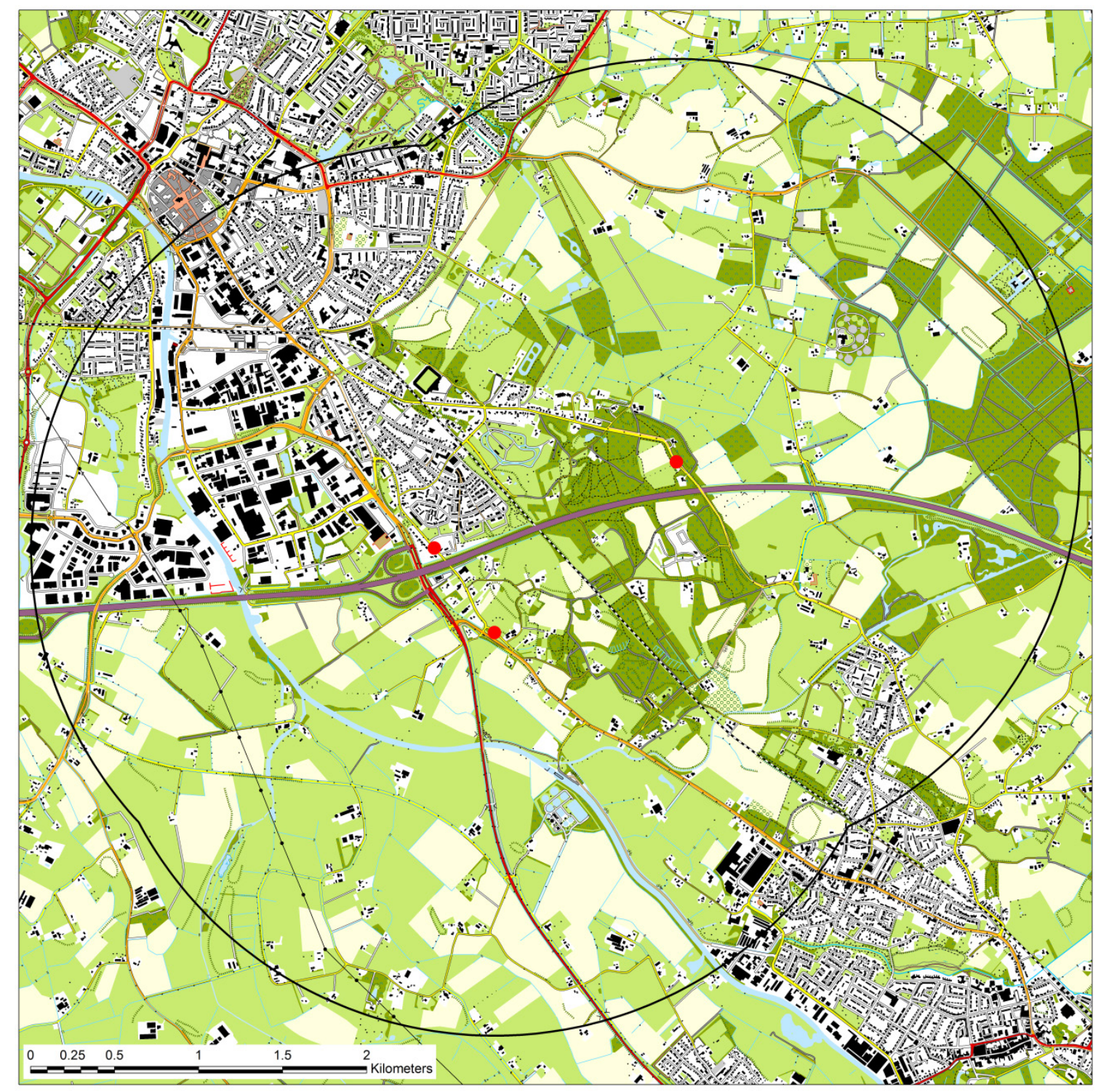

Figuur 4.1 Ligging van het studiegebied bij Doetinchem. De rode stippen geven de vindplaatsen aan van de gevonden dode Wasberen.

De camera's zijn eenmaal per twee weken gecontroleerd, waarbij de gemaakte foto's zijn gedownload, de batterijen zo nodig zijn vervangen en het lokaas is aangevuld. Het gebruik van infraroodcameravallen voor de detectie van Wasberen is zeer geschikt, omdat de dieren mobiel zijn, niet reageren op flitslicht van de camera's en door hun nieuwsgierige aard eenvoudig kunnen worden gelokt (zie ook Michler et al. 2008). In rijksweg A18 zijn binnen het studiegebied enkele faunapassages voor middelgrote zoogdieren aanwezig. Dit betreft drie dassentunnels en looprichels onder de brug over de Bielheimerbeek. Het gebruik van deze faunapassages door fauna is onderzocht in de periode 2012-2013 (Anvelink \& Den Bol, 2013). Tijdens dit onderzoek is gebruik door Wasberen niet vastgesteld. ${ }^{3}$ Hierin is mogelijk verandering gekomen gezien de ligging van de drie vindplekken van dode Wasberen, zowel ten noorden als ten zuiden van deze rijksweg. De faunapassages zijn dan ook als kansrijke plekken voor het detecteren van Wasberen gezien.

\footnotetext{
3 In de periode 2011-2015 is vanuit de Werkgroep Boommarter Achterhoek en Liemers door J. Bakker onderzoek met cameravallen gedaan naar het voorkomen van de Boommarter in de omgeving van Landgoed Slangenburg. Vier van de tien cameraval-locaties lagen binnen ons studiegebied. Tijdens dit onderzoek zijn - binnen en buiten ons studiegebied geen Wasberen geregistreerd.
} 


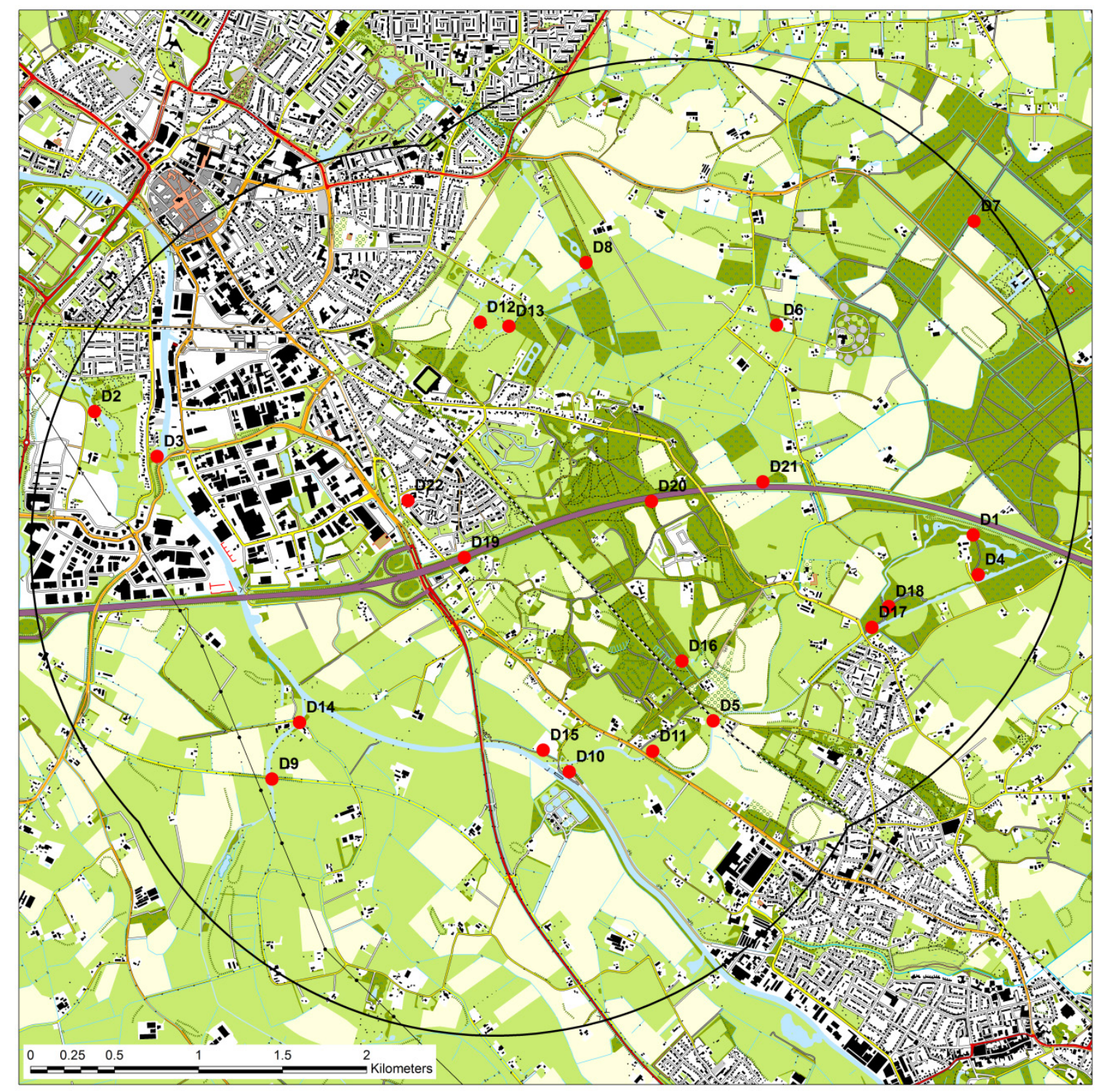

Figuur 4.2 De locaties binnen het studiegebied waar infrarood-cameravallen zijn uitgezet.

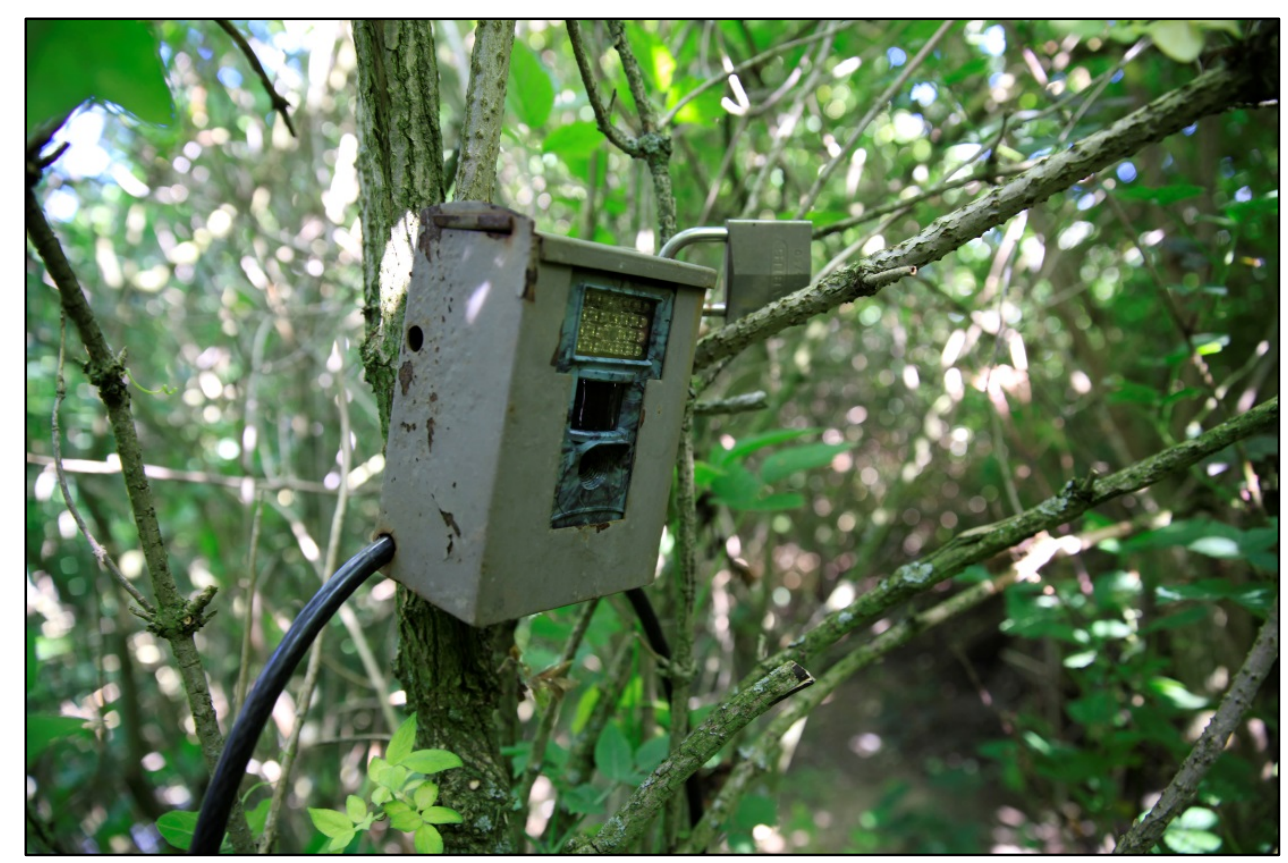

Figuur 4.3 Infrarood-cameraval. 


\subsubsection{Sporenonderzoek}

Binnen het studiegebied is actief gezocht naar sporen die duiden op de aanwezigheid van Wasberen. Hierbij moet men denken aan pootafdrukken, uitwerpselen, haren, krabsporen, vraatsporen, prooiresten e.d. Figuur 4.4 geeft een overzicht van de paden die zijn afgespeurd. Dit betrof vooral onverharde paden die na regenval modderig werden en drassige bermen. Ieder pad is tijdens de onderzoeksperiode vijfmaal bezocht. Daarnaast zijn sporenbedden geplaatst op de looprichels onder de brug bij de Bielheimerbeek. Een sporenbed bestaat uit een 'inktbed' met aan weerszijden een strook papier (figuur 4.5). De 'inkt' is een mengsel van parafine-olie en koolstofpoeder, aangebracht op een sponzen matje. Dieren die het inktbed passeren, laten vervolgens pootafdrukken achter op het papier. Ervaringen met deze onderzoeksmethode laten zien dat de meeste zoogdiersoorten zich niet door de 'inkt' laten weerhouden om te passeren (zie o.a. Brandjes et al. 2002). Hoewel de Wasbeer in Nederland slechts incidenteel is geregistreerd met behulp van een sporenbed van dit type (o.a. Brandjes et al. 2002), verwachten wij dat deze soort de sporenbedden niet als een barrière zal zien.
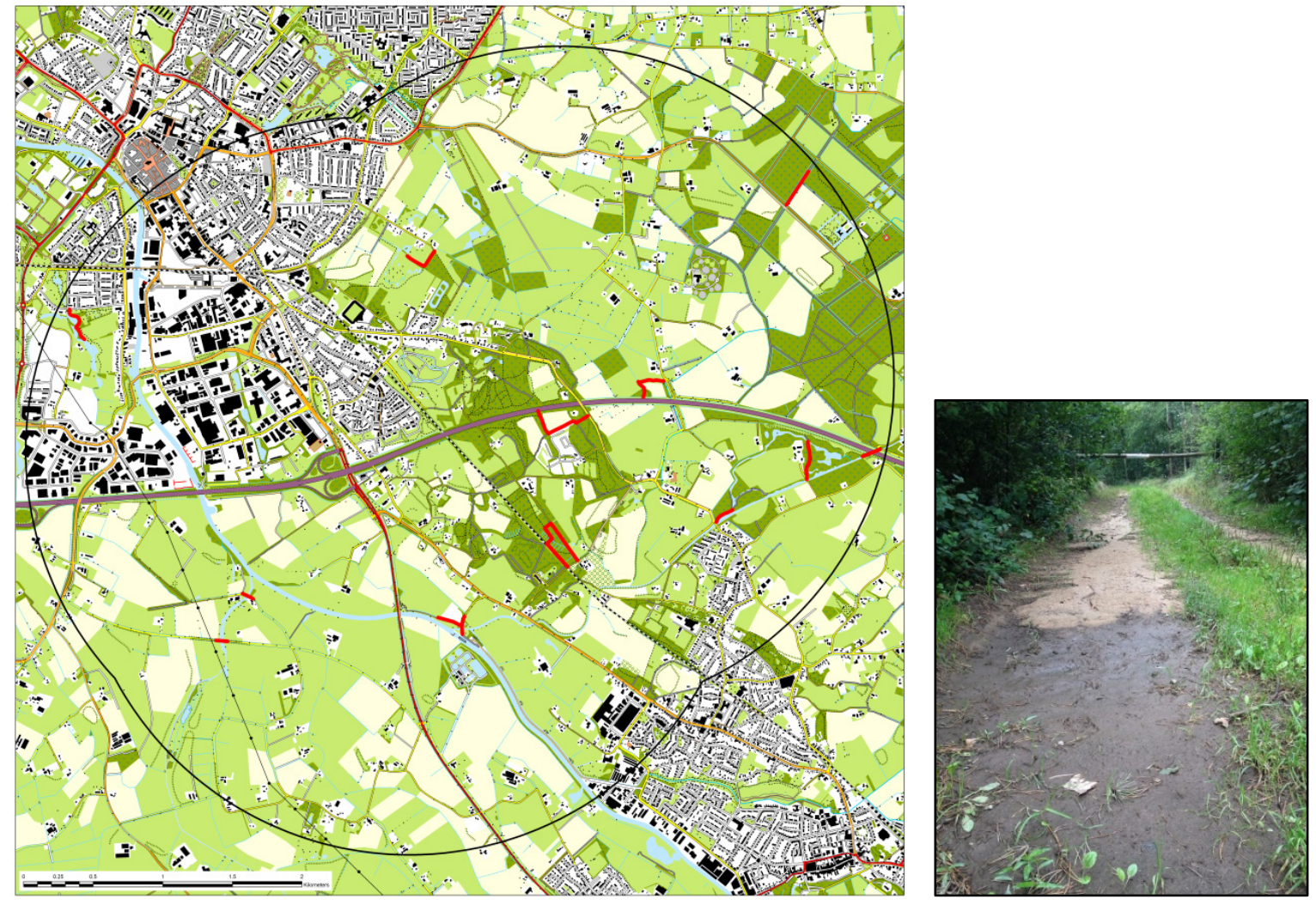

Figuur 4.4 Paden en bermen die tijdens de onderzoeksperiode frequent zijn onderzocht op sporen van Wasberen. Foto rechts: Een modderig bospad kort na regenval - geschikt voor sporenonderzoek.

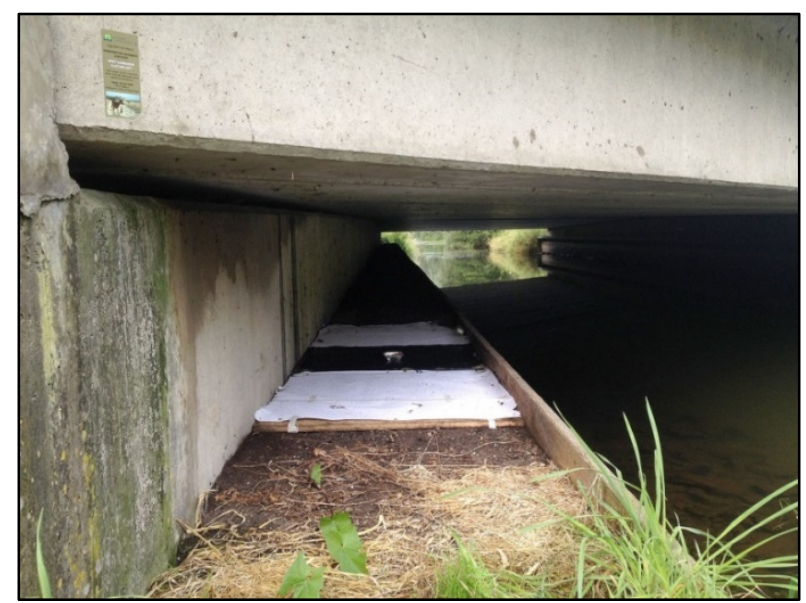

Figuur 4.5 Sporenbed op een looprichel onder de brug over de Bielheimerbeek. 


\subsubsection{Buurtonderzoek}

Binnen het studiegebied zijn buurtbewoners - dus zowel in de stad als in het buitengebied - benaderd en gevraagd naar eventuele waarnemingen van Wasberen (figuur 4.6). Niet iedereen is bekend met websites als waarneming. $\mathrm{nl}$ of neemt de moeite om waarnemingen door te geven. De kans is daarom aanwezig dat bewoners vaker Wasberen zien (of zelfs voeren), zonder dat dit in de bestaande gegevensbestanden zichtbaar is. Tijdens het buurtonderzoek verspreidden we een informatiefolder met duidelijke foto's van de Wasbeer om verwarring met andere soorten te voorkomen (bijlage 7). Wanneer bewoners waarnemingen meldden, is geprobeerd om datum en plaats zo nauwkeurig mogelijk te achterhalen. Als de waarneming recent was, is onderzocht of op de vindplek een infraroodcameraval kon worden geïnstalleerd. Naast buurtbewoners is ook contact gelegd met Gemeente Doetinchem, Wildbeheereenheid Zelhem-Doetinchem, Zoogdierwerkgroep IVN De Oude IJsselstreek en Waterschap Rijn en IJssel.

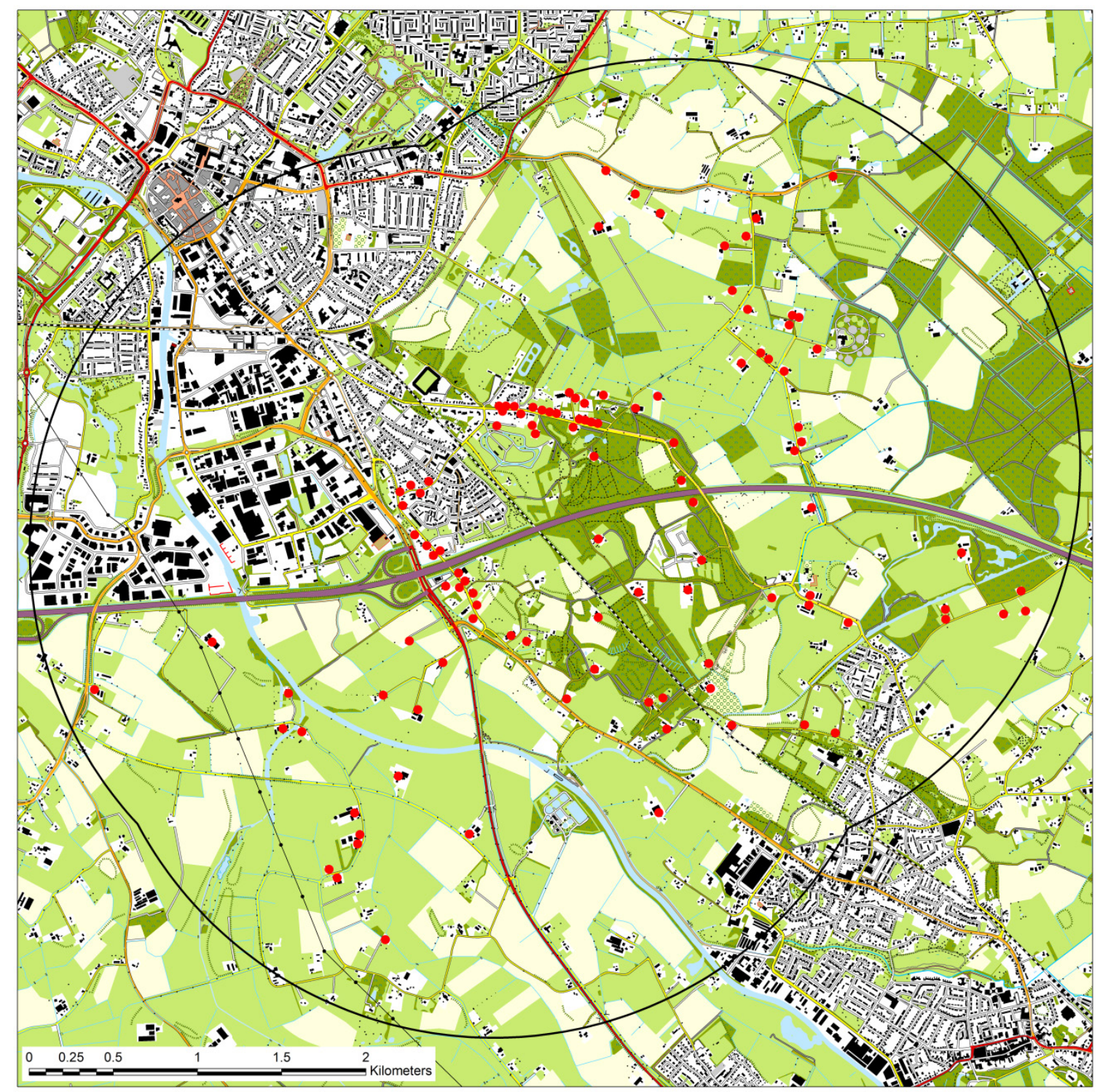

Figuur 4.6 Overzicht van buurtbewoners die benaderd zijn.

\subsubsection{Vaststellen reproductie}

Reproductie stellen we vast aan de hand van (1) camerabeelden met jonge dieren, (2) pootafdrukken van jonge dieren en/of directe waarnemingen van jonge dieren door bewoners. Het areaal wordt (globaal) bepaald op basis van de locaties waar Wasberen met de cameravallen zijn gefotografeerd, 
sporen zijn gevonden of directe waarnemingen door bewoners zijn gedaan. Wasberen leiden in

principe een solitair bestaan. De jongen worden geboren in april of mei en blijven bij de moeder tot de herfst, of zelfs tot het volgende voorjaar. Hoewel de jongen in de maanden juli-augustus al nagenoeg de lichaamsgrootte van volwassen dieren hebben, is een groep dieren (vrouw met jongen) een indicatie voor reproductie. Daarnaast zijn de jonge dieren in deze periode nog te herkennen aan hun (speelse) gedrag.

\subsection{Resultaat}

De infrarood-cameravallen hebben meer dan 120.000 foto's genomen, onder meer van Ree, Das, Steenmarter, Bunzing, Egel, Eekhoorn, Haas, Konijn, Bruine rat en Bosmuis. De camera's hebben echter geen Wasberen geregistreerd.

Tijdens het sporenonderzoek op onverharde paden en in drassige bermen zijn geen sporen van Wasberen gevonden. Op het sporenbed op de looprichels langs de Bielheimerbeek zijn geen sporen van Wasberen geregistreerd.

Het buurtonderzoek heeft twee reacties opgeleverd:

- De familie Migchelbrink in Doetinchem (Oude Terborgseweg) meldde op 20 augustus 2015 "een vreemde kat" in de achtertuin en stuurde fotomateriaal van uitwerpselen. De uitwerpselen lijken niet afkomstig van een Wasbeer. Omdat de plek van deze melding zeer dicht bij de vindplek van een van de dode Wasberen ligt, is hier gedurende een week een cameraval geplaatst. Met de cameraval is geen Wasbeer geregistreerd.

- De familie Verboom in Gaanderen (Watertapweg) meldde op 3 oktober 2015 pootafdrukken op een zitbank in de voortuin. De afdrukken vertoonden gelijkenis met die van een Wasbeer, maar op basis van het fotomateriaal kon niet met zekerheid worden vastgesteld of het hier om een Wasbeer ging.

\subsection{Conclusies}

- In dit onderzoek zijn in de omgeving van Doetinchem geen Wasberen geregistreerd met behulp van cameravallen en sporenonderzoek.

- Door buurtbewoners gemelde pootafdrukken in Gaanderen zijn geclassificeerd als 'mogelijk van een Wasbeer'.

- Er zijn geen aanwijzingen dat er in het studiegebied sprake is van een lokaal gevestigde populatie. 


\section{Veldinventarisatie Biesbosch}

\section{$5.1 \quad$ Inleiding}

In dit hoofdstuk richten we ons op de vraag of er in het Dordtse Biesbosch meerdere Wasberen voorkomen en zo ja, of hier sprake is van een lokaal gevestigde populatie. Zoals vastgesteld tijdens het onderzoek naar het voorkomen van Wasberen in Nederland, zijn er in dit moerasgebied in de periode 2014-2015 frequent foto's gemaakt van een Wasbeer (zie hoofdstuk 2). Op meerdere foto's gaat het om hetzelfde individu - een mannelijk dier -, maar dit kon niet in alle gevallen worden vastgesteld. Mogelijk zijn er dus meerdere dieren en wellicht is er sprake van voortplanting. In overleg met BuRO van de NVWA is daarom besloten om in dit deel van de Biesbosch een veldinventarisatie uit te voeren om vast te stellen of hier sprake is van een lokaal gevestigde populatie of niet.

\subsection{Methode}

Het voorkomen van Wasberen in de Dordtse Biesbosch is onderzocht met behulp van (1) infraroodcameravallen en (2) sporenonderzoek. Buurtonderzoek is niet uitgevoerd, omdat het een onbewoond en moeilijk toegankelijk moerasgebied betreft. Genoemde onderzoekstechnieken zijn tevens gebruikt om vast te stellen of er reproductie plaatsvindt en wat het areaal is van de soort.

\subsubsection{Afbakening studiegebied}

Het studiegebied bestaat uit het moerasgebied van de Dordtse Biesbosch, net ten zuiden van Dordrecht en ten oosten van de Dordtse Kil. Het omliggende landbouwgebied is niet in het onderzoek betrokken, omdat dit een intensief agrarisch gebruik kent en als ongeschikt habitat voor de Wasbeer is beoordeeld. De Brabantse Biesbosch, ten zuiden van de Nieuwe Merwede, is niet in het onderzoek betrokken omdat er in dit gebied (vooralsnog) geen Wasberen zijn gemeld.

\subsubsection{Infrarood-cameravallen}

In de periode 26 november 2015-10 maart $2016^{4}$ zijn binnen het studiegebied op 11 kansrijke locaties cameravallen (merk: ACORN en KÖNIG) met infrarooddetectie geplaatst (figuur 5.1). Hierbij is nauw samengewerkt met de Natuur- en Vogelwacht Biesbosch die de waarnemingen van Wasberen in 2014-2015 heeft gedaan. We gebruikten lokaas (kattenvoer) om de kans op detectie te vergroten. De cameravallen zijn op circa 1,5 m hoogte geplaatst in verband met de (grote) wisselingen in de waterstand binnen het gebied. Het totaal aantal valnachten was 1.067. Het gemiddeld aantal valnachten per camera-locatie was 97. Bijlage 6 geeft een overzicht van de periode en het aantal valnachten per camera-locatie. De camera's zijn eenmaal per twee weken gecontroleerd, waarbij de gemaakte foto's zijn gedownload, de batterijen zo nodig zijn vervangen en het lokaas is aangevuld.

\subsubsection{Sporenonderzoek}

Binnen het studiegebied is tijdens het uitzetten van de cameravallen actief gezocht naar sporen die duiden op de aanwezigheid van Wasberen. Hierbij moet men denken aan pootafdrukken, uitwerpselen, haren, krabsporen, vraatsporen, prooiresten e.d.

\footnotetext{
4 Wasberen zijn minder actief bij koud winterweer. Er is daarom gekozen voor een onderzoeksperiode van ruim drie maanden om de kans op detectie te vergroten. Omdat de winter van 2015/2016 zeer zacht was, is een verlenging van het onderzoek tot in het voorjaar als onnodig beoordeeld.
} 


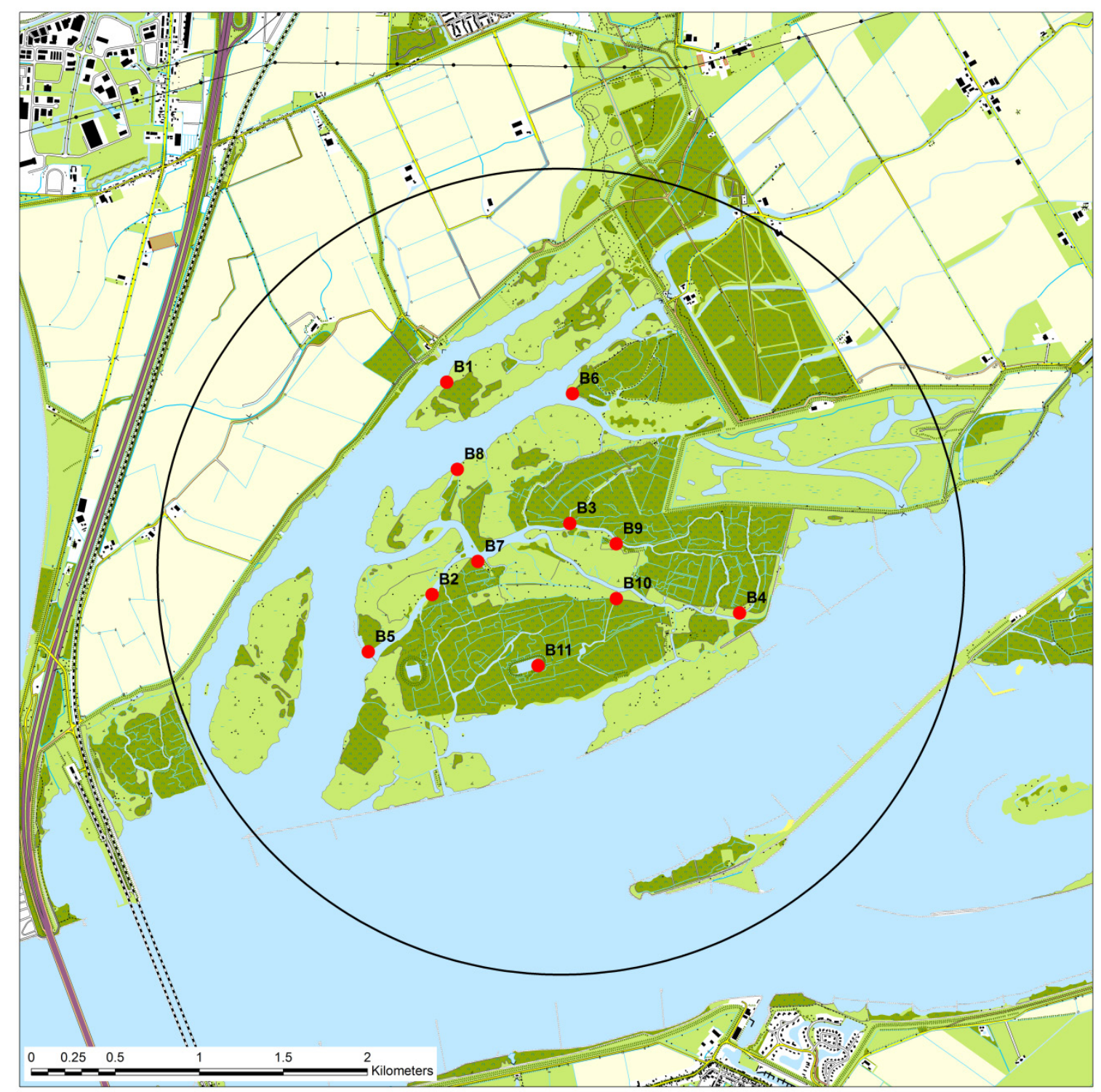

Figuur 5.1 De locaties binnen het studiegebied waar infrarood-cameravallen zijn uitgezet.

\subsubsection{Vaststellen reproductie}

Reproductie stellen we vast aan de hand van (1) camerabeelden met jonge dieren en (2) pootafdrukken van jonge dieren. Het areaal wordt (globaal) bepaald op basis van de locaties waar Wasberen met de cameravallen zijn gefotografeerd of sporen zijn gevonden.

\subsection{Resultaat}

De infrarood-cameravallen hebben meer dan 8.000 foto's genomen, onder meer van Ree, Vos, Bever, Boommarter, Bunzing, Muskusrat, Bruine rat en Bosmuis. De camera's hebben viermaal een Wasbeer geregistreerd, op drie verschillende plekken in het gebied (tabel 5.1). In alle gevallen betrof het een volwassen dier. Het geslacht van het dier kon op basis van de camerabeelden niet worden vastgesteld. Op basis van de staarttekening van de waargenomen Wasberen, hoewel niet in alle gevallen even goed zichtbaar, vermoeden wij dat het hier om één individu gaat (figuur 5.2). Bij vergelijking met de door de Natuur- en Vogelwacht Biesbosch gemaakte camerabeelden uit 2014 en 2015 lijkt de in dit onderzoek geregistreerde Wasbeer hetzelfde dier te zijn (J. Mulder, pers. communicatie). Dit zou betekenen dat het hier om een mannelijk dier gaat. 
De eerste waarneming is gedaan aan de noordrand van het moerasgebied (zie ook figuur 5.1). De tweede waarneming is gedaan aan de zuidrand van het gebied, nabij de Nieuwe Merwede. Deze twee locaties liggen hemelsbreed circa 2,5 kilometer uit elkaar. De derde waarneming is opnieuw in het noordelijk deel van het gebied gedaan, nabij de oever van het Noorderdiep. Deze plek ligt hemelsbreed circa 2 kilometer vanaf de tweede vindplek. De laatste waarneming is op dezelfde plek als de eerste waarneming gedaan. Tijdens het sporenonderzoek zijn er geen sporen van Wasberen gevonden. Dit is vooral een gevolg van de dichte begroeiing en plaatselijk hoge waterstanden.

Tabel 5.1 Tijdens de onderzoeksperiode met cameravallen geregistreerde Wasberen in de Dordtse Biesbosch.

\begin{tabular}{lllll} 
Datum & Locatie & Aantal & Geslacht & Leeftijd \\
5 december 2015 & B1 & 1 & Onbekend & Adult \\
\hline 27 december 2015 & B4 & 1 & Onbekend & Adult \\
\hline 5 maart 2016 & B8 & 1 & Onbekend & Adult \\
\hline 6 maart 2016 & B1 & 1 & Onbekend & Adult \\
\hline
\end{tabular}

\subsection{Conclusies}

- In dit onderzoek is het voorkomen van de Wasbeer in de Dordtse Biesbosch bevestigd. Naar verwachting gaat het om één individu, een volwassen man.

- De drie vindplekken suggereren dat het dier het hele moerasgebied als leefgebied heeft.

- Er zijn geen aanwijzingen dat er in het studiegebied sprake is van een lokaal gevestigde populatie. 

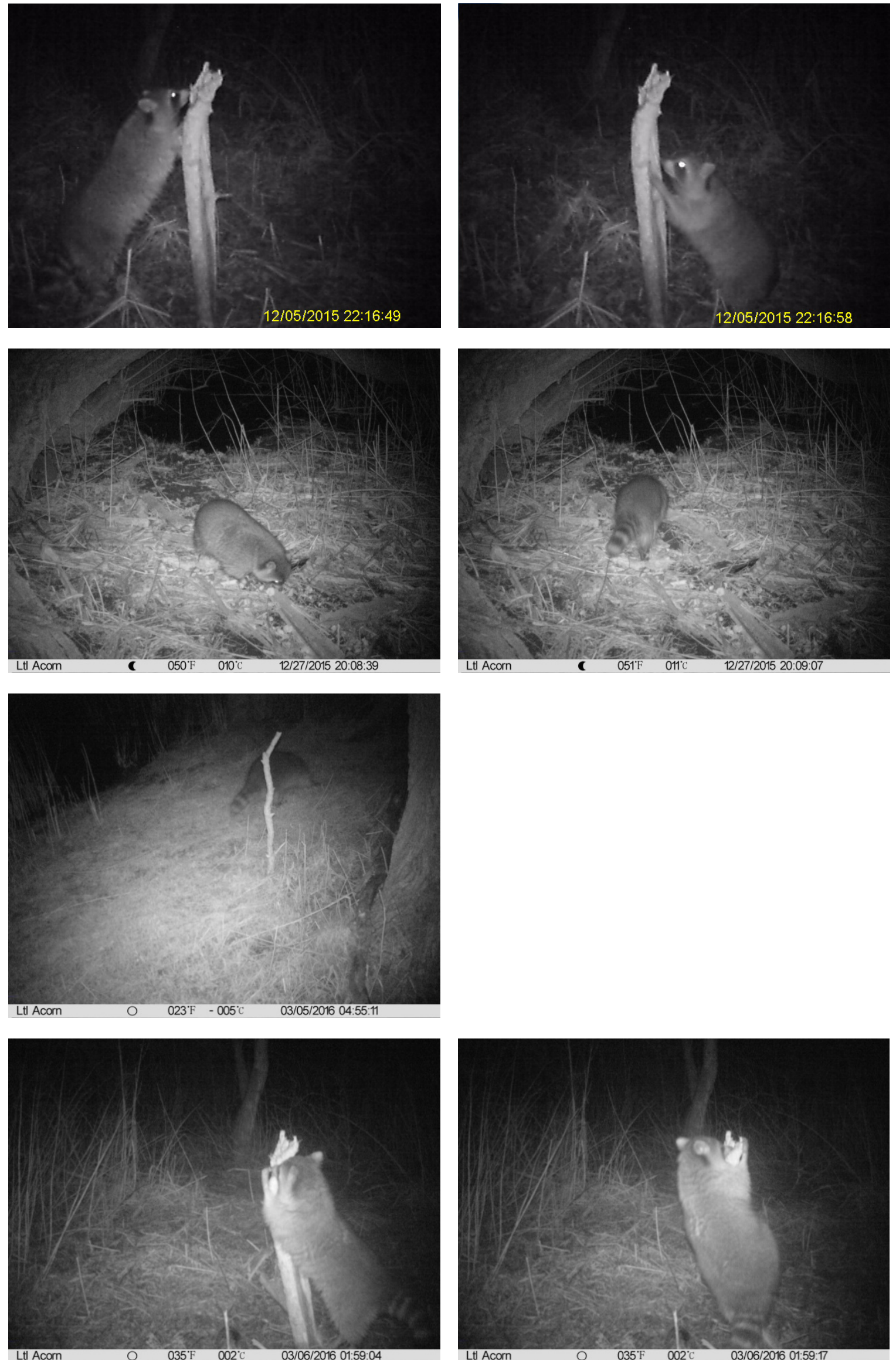

Figuur 5.2 Camerabeelden van de waargenomen Wasberen in de Dordtse Biesbosch. 


\section{Aanbevelingen}

Naar aanleiding van dit onderzoek doen wij de volgende aanbevelingen:

- Wij bevelen aan om de komende jaren het voorkomen van Wasberen in de grensstreek met Duitsland te monitoren. De verwachting is dat het aantal Wasberen in de grensstreek op niet al te lange termijn zal toenemen, gezien de snelle groei van de populaties in Duitsland en de snelle uitbreiding van hun areaal daar.

- Wij bevelen hetzelfde aan voor de grensstreek met België in Zuid-Limburg, omdat recentelijk ook het aantal waarnemingen in Wallonië toeneemt.

- Wij bevelen aan een helder plan van aanpak op te stellen voordat de Wasbeer zich definitief vestigt en binnen onze landsgrenzen één of meer populaties vormt. Geldt er een nulstandbeleid, accepteren we lage aantallen of laten we de soort geheel ongemoeid omdat elders bestrijding niet effectief is gebleken? 


\section{Dankwoord}

Een groot aantal mensen heeft een bijdrage geleverd aan dit onderzoek. We willen hen allen hartelijk danken!

We bedanken Sander Smolders die namens BuRO van de Nederlandse Voedsel- en Warenautoriteit als contactpersoon optrad voor het onderzoek.

We bedanken Eva Schippers, Godelieve Kranendonk en Heleen Post-van Engeldorp Gastelaars (Stichting AAP), Femke Hamelynck (Natuurloket; NDFF), Joke van der Giessen (RIVM), Marja Kik (DWHC), en Jaap Mulder (Bureau Mulder-natuurlijk) voor het leveren van informatie over het voorkomen van de Wasbeer in Nederland.

We bedanken Reinhild Gräber en Oliver Keuling (Institut für Terrestrische und Aquatische Wildtierforschung (ITAW)), Berit en Frank Michler (Hochschule für nachhaltige Entwicklung Eberswalde (FH), Fachbereich Wald \& Umwelt, Fachgebiet Wildbiologie, Wildtiermanagement \& Jagdbetriebskunde), Norman Stier (TU Dresden, Forstzoologie, AG Wildtierforschung) en Walburga Lutz (Forschungsstelle für Jagdkunde und Wildschadenverhütung) voor het leveren van informatie over het voorkomen van de Wasbeer in Duitsland.

We bedanken Tjibbe Hunink (Staatsbosbeheer), Ronald Langendoen (Gemeente Doetinchem), Jop Bakker (Werkgroep Boommarter Achterhoek en Liemers), Henriëtte van der Loo (Zoogdierwerkgroep IVN De Oude IJsselstreek) en Bert Vinkenborg (WBE Zelhem-Doetinchem) voor het leveren van informatie over het voorkomen van de Wasbeer in de omgeving van Doetinchem. We bedanken Amber van Beek (Hogeschool Van Hall-Larenstein) voor haar bijdrage aan het veldonderzoek in studiegebied Doetinchem. We bedanken de familie Verboom en de familie Migchelbrink voor het melden van hun waarnemingen.

We bedanken Levi Verhoek en Laura Jebbink (Wageningen Universiteit) voor het uitvoeren van een groot deel van het veldwerk in de Dordtse Biesbosch en het analyseren van de camerabeelden. We bedanken Rob Haan (Natuur- en Vogelwacht Biesbosch) voor het leveren van gegevens en de hulp bij het uitvoeren van het veldwerk in de Dordtse Biesbosch. 


\section{Literatuur}

Anthony, J.A., J.E. Childs, G.E. Glass, G.W. Korch, L. Ross \& J.K. Grigor, 1990. Land use associations and changes in population indices of urban raccoons during a rabies epizootic. Journal of Wildlife Disease 26: 170-179.

Anvelink, B. \& K. den Bol, 2013. Kwaliteit en kosten van verschillende monitoringstechnieken bij gebruik bij faunapassages en hun omgeving. Studentenrapport. Hogeschool Van Hall-Larenstein, Leeuwarden.

Barding, E.E. \& T.A. Nelson, 2008. Raccoons use habitat edges in Northern Illinois. The American Naturalist 159 (2): 394-402.

Bartoszewicz, M., H. Okarma, A. Zalewski \& J. Szczesna, 2008. Ecology of the raccoon (Procyon lotor) from Western Poland. Annales Zoologici Fennici 45 (4): 291-298.

Brandjes, G.J., R. van Eekelen, K. Krijgsveld en G.F.J. Smit, 2002. Het gebruik van faunabuizen onder rijkswegen. Resultaten literatuur- en veldonderzoek. DWW Ontsnipperingsreeks deel 43. Rapport DWW-2002-123. Rijkswaterstaat DWW, Delft / Bureau Waardenburg, Culemborg.

Fischer, M.L., A. Hochkirch, M. Heddergott, C. Schulze, H.E. Anheyer-Behmenburg, J. Lang et al., 2015. Historical invasion records can be misleading: Genetic evidence for multiple introductions of invasive raccoons (Procyon lotor) in Germany. PLoS ONE 10 (5): e0125441. doi:10.1371/journal.pone.0125441

Frantz, A.C., P. Cyriacks \& L. Schley, 2005. Spatial behaviour of a female raccoon (Procyon lotor) at the edge of the species' European distribution range. European Journal for Wildlife Research 51 : 126-130.

Gräber, R., E. Strauß \& S. Johanshon, 2014. Wild und Jagd - Landesjagdbericht 2013/14. Niedersächsisches Ministerium für Ernährung, Landwirtschaft und Verbraucherschutz (Hrsg.), Hannover, Duitsland.

Hermes, N., B.A. Köhnemann, F.U. Michler \& M. Roth, 2011. Radiotelemetrische Untersuchungen zur Habitatnutzung des Waschbären (Procyon lotor L., 1758) im Müritz-Nationalpark Beiträge zur Jagd- und Wildforschng 36: 557-572.

Hohmann, U., R. Gerhard \& M. Kasper, 2000. Home range size of adult raccoons (Procyon lotor) in Germany. Zeitschrift fur Säugetierkunde 65: 124-127.

Hohmann, U., S. Voigt \& U. Andreas, 2001. Quo vadis raccoon? New visitors in our backyards - On the urbanization of an allochtone carnivore in Germany. Onbekende bron.

Ingle, M.E., S.G. Dunbar, M.A. Gathany, M.M. Vasser, J.L. Bartsch, K.R. Guffey, C.J. Knox, A.N. Nolan, C.E. Rowlands \& E.C. Trigg, 2014. Predicting Baylisascaris procyonis roundworm prevalence, presence and abundance in raccoons (Procyon lotor) of southwestern Ohio using landscape features. International Journal for Parasitology: Parasites and Wildlife 3 (2): 113-117.

Lagoni-Hansen, A., 1981. Der Waschbär. Lebensweise und Ausbreitung. Verlag Dieter Hoffmann, Mainz, Duitsland.

Lammertsma, D.R., G.W.T.A. Groot Bruinderink \& S. Broekhuizen, 2008. Wasberen (Procyon lotor L. 1758) in Nederland: verspreiding, ecologie en mogelijke gevolgen voor Nederland. Alterra-rapport 1741. Alterra, Wageningen.

Maas, M., F. Franssen, H. Sprong, C. van Dam \& J. van der Giessen, 2012. Bayliascaris spp. in the Netherlands. A quick-scan of these emerging parasites and their potential zoonotic risk. RIVM Letter report 149/2012. RIVM, Bilthoven.

Michler, F.U.F., 2003. Untersuchungen zur Raumnutzung des Waschbären (Procyon lotor, L. 1758) im urbanen Lebensraum am Beispiel der Stadt Kassel (Nordhessen). Thesis. Institut für Zoologie, Martin-Luther-Universität, Halle-Wittenberg, Duitsland.

Michler, F.U. \& B.A. Köhnemann, 2010. Tierische Spitzenleistung - Abwanderungsverhalten von Waschbären (Procyon lotor L., 1758) in Norddeutschland. Labus 31: 52-59.

Michler, F.U., 2006. Mehr Sammler als Jäger? Biologie des Waschbären. Neubürger auf den Vormarsch. Sonderheft unsere Jagd, Pirsch, Niedersächsische Jäger: 38-49.

Michler, F.U., B.A. Köhnemann \& M. Roth, 2008. Camera traps - a suitable method to investigate the population ecology of raccoons (Procyon lotor L., 1758). Poster. DGS, Wenen, Oostenrijk. 
Montizaan, M. \& D. Bekker, 2015. Gevaarlijke wasberenspoelworm in Nederland. Zoogdier 26 (2): 18-19.

Nentwig, W., E. Kühnel \& S. Bacher, 2010. A Generic impact-scoring system applied to alien mammals in Europe. Conservation Biology 24 (1): 302-311.

Newbury, R.K. \& T.A. Nelson, 2007. Habitat selection and movements of raccoons on a grassland reserve managed for imperiled birds. Journal of Mammalogy 88 (4): 1082-1089.

Ortmann, S., B.A. Köhnemann, F.U. Michler \& M. Roth, 2011. Radiotelemetrische Untersuchung des Raum-Zeit-Verhaltens adulter Waschbären (Procyon lotor L., 1758) im Müritz-Nationalpark (Mecklenburg-Vorpommern). Beiträge zur Jagd- und Wildforschng 36: 539-556.

Smith, H.T., 2002. An extraordinary raccoon Procyon lotor density at an urban park. Canadian Field Naturalist 116 (4): 636-639.

Troyer, E.M., S.E. Cameron Devitt, M.E. Sunquist, V.R. Goswami \& M.K. Oli, 2014. Survival, recruitment, and population growth rate of an important mesopredator: The Northern Raccoon. PLoS ONE 9 (6): e98535. doi:10.1371/journal.pone.0098535

Zeveloff, S.I., 2002. Raccoons: A Natural History. Smithsonian Institution, Washington, D.C., VS. 


\section{Bijlage 1 Homeranges Wasbeer}

Tabel B1.1 In de Europese literatuur aangetroffen home ranges voor Wasberen, onderscheiden naar habitat, geslacht en seizoen.

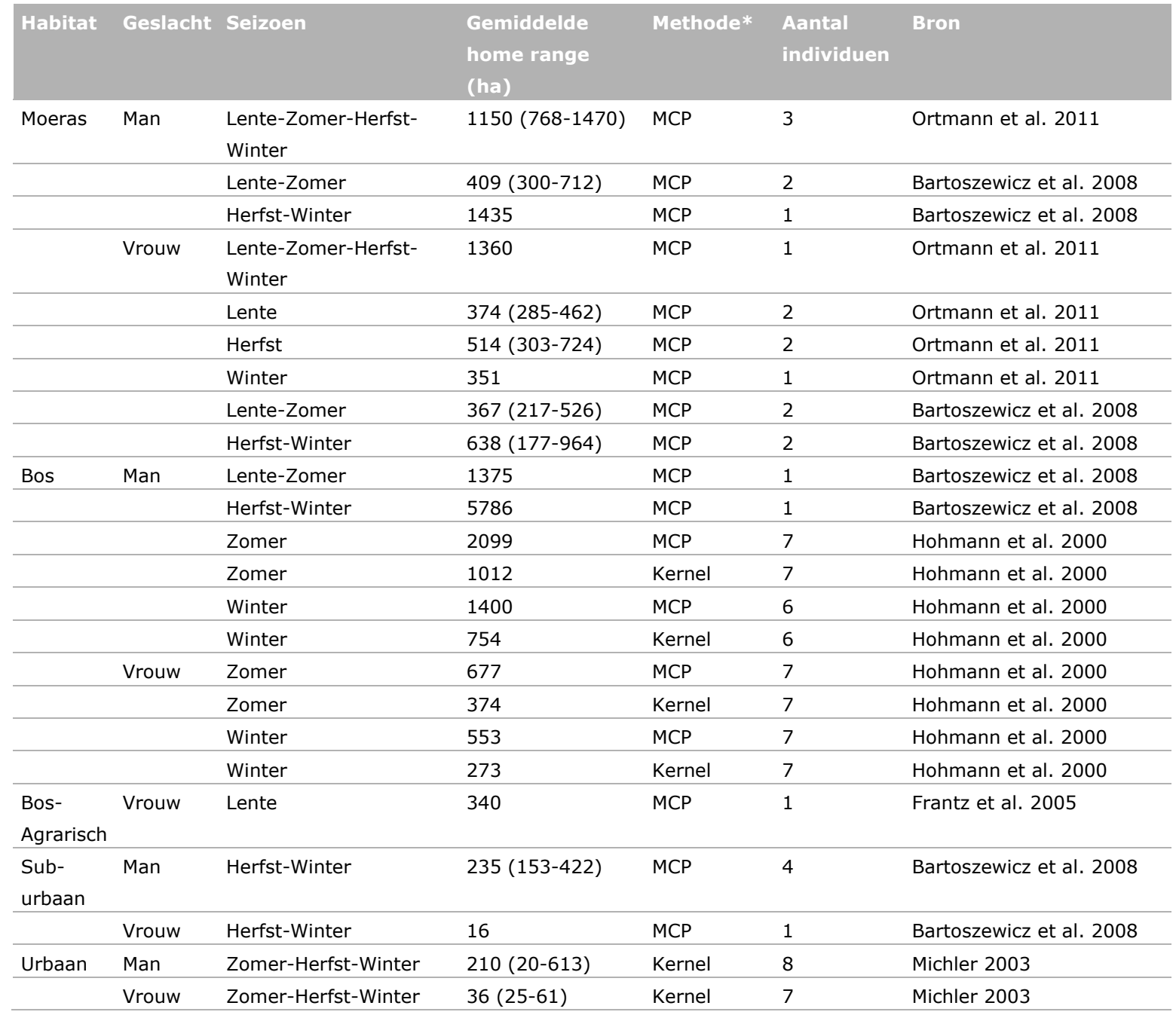

* MCP $=$ minimum convex polygon with $100 \%$ of locations

Kernel $=$ adaptive kernel with $95 \%$ of locations 


\section{Bijlage 2 Recente meldingen van Wasberen in Nederland}

Tabel B2.1 Meldingen van Wasberen in Nederland in de periode 1 juli 2015-1 juli 2016.

\begin{tabular}{|c|c|c|c|c|c|c|c|c|}
\hline Jaar & Mnd & Dag & Aantal & $\begin{array}{l}\text { Type } \\
\text { melding }\end{array}$ & Provincie & Locatie & Status & Bron \\
\hline 2015 & 7 & 12 & 1 & vs & UT & A2 - Zijdeveld & NO & waarneming.nl \\
\hline 2015 & 8 & 3 & 1 & on & NB & A73 - Heeswijk & NO & waarneming.nl \\
\hline 2015 & 8 & 3 & 1 & Idc & LI & Geleenbeek & G & Alterra \\
\hline 2015 & 9 & 17 & 1 & Idv & NB & Hunsel & $z$ & J. Mulder \\
\hline 2015 & 9 & 18 & 1 & Idv & LI & Siebengewald & z & J. Mulder \\
\hline 2015 & 10 & 11 & 1 & $\mathrm{sp}$ & GE & Heerde - Heerderstrand & NO & waarneming.nl \\
\hline 2015 & 10 & 12 & 1 & vs & LI & $\begin{array}{l}\text { Schinveld - Rode Beekdal } \\
\text { Noord }\end{array}$ & NO & waarneming.nl \\
\hline 2015 & 10 & 20 & 1 & $\mathrm{Idz}$ & NB & Valkenswaard & $z$ & J. Mulder \\
\hline 2015 & 10 & 28 & 1 & vs & LI & A2 - Weert & NO & waarneming.nl \\
\hline 2015 & 11 & 5 & 1 & $\mathrm{Idz}$ & UT & Werkhoven & z & J. Mulder \\
\hline 2015 & 11 & 11 & 1 & vs & LI & A76 - Simpelveld & G & $\begin{array}{l}\text { ARK } \\
\text { Natuurontwikkeling }\end{array}$ \\
\hline 2015 & 11 & 12 & 1 & on & GR & Weite & NO & waarneming.nl \\
\hline 2015 & 11 & 29 & 1 & Idv & LI & Roermond & z & J. Mulder \\
\hline 2016 & 1 & 13 & 1 & Idc & FR & $\begin{array}{l}\text { Lindevallei } \\
\text { (Natuurreservaat) }\end{array}$ & G & waarneming.nl \\
\hline 2016 & 1 & 21 & 1 & vs & OV & Buurse & W & J. Mulder \\
\hline 2016 & 2 & 12 & 1 & vs & NB & A77 - Boxmeer & G & waarneming.nl \\
\hline 2016 & 2 & 24 & 1 & $\mathrm{Idz}$ & NB & Afferden/Sambeek - stuw & G & waarneming.nl \\
\hline 2016 & 4 & - & 1 & Idz & $\mathrm{GL}$ & Stroe & W & J. Mulder \\
\hline 2016 & 4 & 14 & 1 & Idc & DR & Anserdennen & z & J. Mulder \\
\hline 2016 & 4 & 24 & 1 & $\mathrm{sp}$ & LI & Afferden (Li.) - Gening & NTB & waarneming.nl \\
\hline 2016 & 5 & 14 & 1 & $\mathrm{Idz}$ & GE & $\begin{array}{l}\text { Lunteren - Klomperweg / } \\
\text { Heuvelseweg }\end{array}$ & NO & waarneming.nl \\
\hline 2016 & 5 & 21 & 1 & on & GE & $\begin{array}{l}\text { Nijmegen - Bottendaal, } \\
\text { Wolfskuil, Nije Veld }\end{array}$ & NO & waarneming.nl \\
\hline 2016 & 5 & 23 & 1 & $\mathrm{Idz}$ & LI & Amstenrade & G & waarneming.nl \\
\hline 2016 & 6 & 6 & 1 & vs & OV & A1 - Holten & NO & waarneming.nl \\
\hline
\end{tabular}

Legenda type melding:

$\begin{array}{lll}\text { Idc } & = & \text { levend dier (cameraval) } \\ \mathrm{Idz} & = & \text { levend dier (zichtwaarneming) } \\ \mathrm{Idv} & = & \text { levend dier (vangst) } \\ \mathrm{vs} & = & \text { verkeersslachtoffer } \\ \mathrm{sp} & = & \text { sporen } \\ \mathrm{on} & = & \text { onbekend }\end{array}$

Legenda status:

$\begin{array}{lll}\mathrm{NO} & = & \text { niet onderzocht } \\ \mathrm{NTB} & = & \text { (nog) niet te beoordelen } \\ \mathrm{G} & = & \text { goedgekeurd } \\ \mathrm{W} & = & \text { warschijnlijk } \\ \mathrm{Z} & = & \text { zeker }\end{array}$



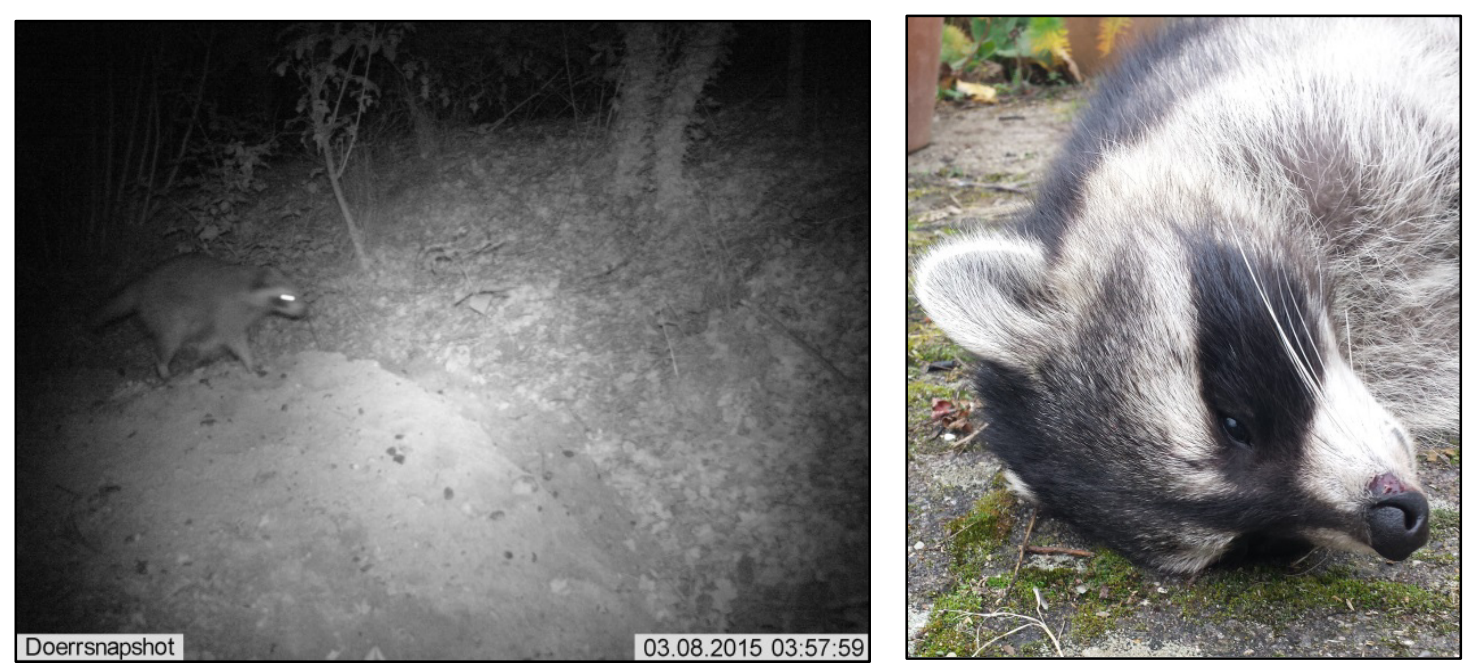

Figuur B2.1 Wasbeer (links) nabij de Geleenbeek in Zuid-Limburg (bron: Alterra) en verkeersslachtoffer (rechts) op de A76 nabij Simpelveld (bron: ARK Natuurontwikkeling). 


\section{Bijlage 3 Waarnemingen van Wasberen in België}

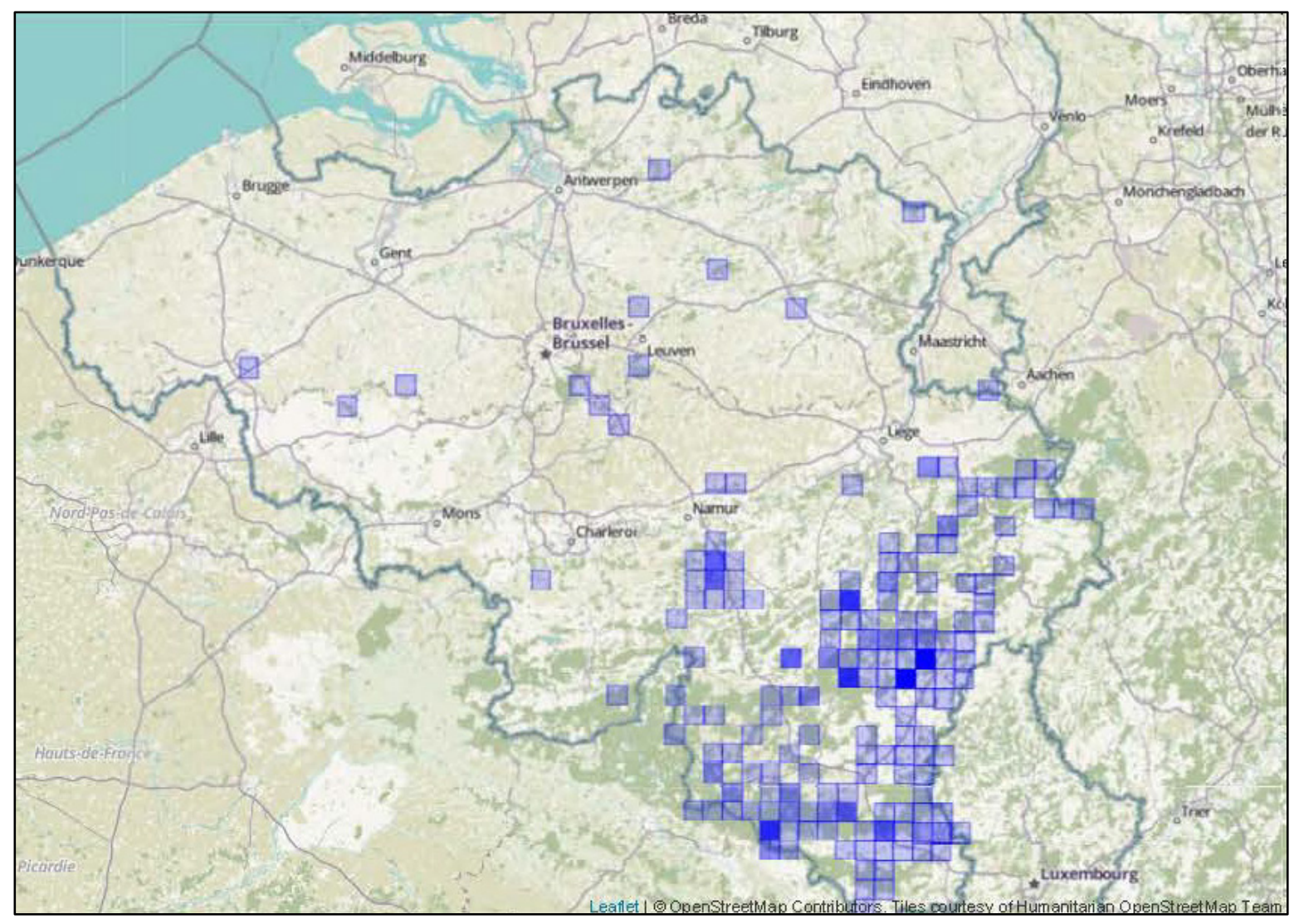

Figuur B3.1 Gevalideerde waarnemingen van Wasberen in België in de laatste zeven jaar (periode 12-6-2009 tot 12-6-2016; bron: Natuurpunt - http://waarnemingen.be). 


\section{Bijlage 4 Contacten Duitsland}

Tabel B4.1 Duitse onderzoeksgroepen met wie contact is gezocht voor informatie over de verspreiding en populatiegroei van de Wasbeer in de Duits-Nederlandse grensstreek.

\begin{tabular}{|c|c|c|c|}
\hline Contactpersonen & Instituut & Plaats & Website \\
\hline $\begin{array}{l}\text { Reinhild Gräber } \\
\text { Oliver Keuling }\end{array}$ & $\begin{array}{l}\text { Institut für Terrestrische und } \\
\text { Aquatische Wildtierforschung } \\
\text { (ITAW) }\end{array}$ & Hannover & $\begin{array}{l}\text { http://www.tiho-hannover.de/kliniken- } \\
\text { institute/institute/institut-fuer-terrestrische-und- } \\
\text { aquatische-wildtierforschung }\end{array}$ \\
\hline $\begin{array}{l}\text { Berit Michler } \\
\text { Frank Michler }\end{array}$ & $\begin{array}{l}\text { Hochschule für nachhaltige } \\
\text { Entwicklung Eberswalde (FH), } \\
\text { Fachbereich Wald \& Umwelt, } \\
\text { Fachgebiet Wildbiologie, } \\
\text { Wildtiermanagement \& } \\
\text { Jagdbetriebskunde }\end{array}$ & Eberswalde & $\begin{array}{l}\text { http://www.hnee.de/de/Fachbereiche/Wald-und- } \\
\text { Umwelt/Fachgebiet-fuer-Wildbiologie- } \\
\text { Wildtiermanagement-Jagdbetriebskunde-FWWJ- } \\
\text { E7555.htm }\end{array}$ \\
\hline Norman Stier & $\begin{array}{l}\text { TU Dresden, Forstzoologie, AG } \\
\text { Wildtierforschung }\end{array}$ & Dresden & http://tu-dresden.de/forst/zoologie \\
\hline Walburga Lutz & $\begin{array}{l}\text { Forschungsstelle für Jagdkunde } \\
\text { und Wildschadenverhütung }\end{array}$ & Bonn & $\begin{array}{l}\text { http://www.lanuv.nrw.de/natur/jagd/forschungsstelle- } \\
\text { fuer-jagdkunde-und-wildschadenverhuetung }\end{array}$ \\
\hline
\end{tabular}




\section{Bijlage 5 Afschot/valwild in Duitsland}

Tabel B5.1 Aantal Wasberen dat in Duitsland is geregistreerd als afschot en valwild, per deelstaat, voor de periode 2003-2014 (bron: Deutscher Jagdverband, Handbuch 2015, www.jagdverband.de).

\begin{tabular}{|c|c|c|c|c|c|c|c|c|c|c|c|}
\hline Deel- & $2003 /$ & $2004 /$ & $2005 /$ & $2006 /$ & $2007 /$ & $2008 /$ & $2009 /$ & $2010 /$ & 2011/ & $2012 /$ & $2013 /$ \\
\hline staat & 2004 & 2005 & 2006 & 2007 & 2008 & 2009 & 2010 & 2011 & 2012 & 2013 & 2014 \\
\hline BW & 68 & 97 & 105 & 79 & 118 & 193 & 214 & 339 & 262 & 585 & 721 \\
\hline BY & 225 & 335 & 323 & 625 & 373 & 371 & 455 & 722 & 618 & 1035 & 927 \\
\hline$B L$ & 2 & 27 & 35 & 4 & 8 & 11 & 8 & 9 & 29 & 90 & 64 \\
\hline BB & 3471 & 4593 & 5712 & 5477 & 7691 & 10580 & 10291 & 11769 & 14495 & 20274 & 21577 \\
\hline $\mathrm{HB}$ & 0 & 0 & 0 & 0 & 2 & 2 & 0 & 1 & 0 & 2 & 1 \\
\hline $\mathrm{HH}$ & 1 & 1 & 0 & 4 & 0 & 1 & 4 & 2 & 1 & 0 & no data \\
\hline $\mathrm{HE}$ & 9991 & 9615 & 11335 & 7853 & 11056 & 16616 & 14921 & 22209 & 17580 & 29159 & 21614 \\
\hline MV & 210 & 357 & 469 & 431 & 857 & 1022 & 1007 & 1644 & 1580 & 2243 & 3896 \\
\hline $\mathrm{NI}$ & 1400 & 1603 & 2426 & 1704 & 3069 & 4093 & 4380 & 6409 & 6176 & 9402 & 8414 \\
\hline NW & 3071 & 3346 & 4617 & 3600 & 5467 & 7212 & 6368 & 8573 & 8437 & 11075 & 8725 \\
\hline $\mathrm{RP}$ & 20 & 30 & 35 & 23 & 30 & 66 & 39 & 79 & 94 & 260 & 214 \\
\hline SL & 0 & 0 & 0 & 0 & 0 & 0 & 9 & 6 & 0 & 1 & 1 \\
\hline SN & 139 & 185 & 326 & 498 & 753 & 1210 & 1454 & 2241 & 3256 & 5305 & 5616 \\
\hline ST & 981 & 1692 & 2166 & 2375 & 3888 & 6239 & 6563 & 8678 & 12090 & 16283 & 16417 \\
\hline $\mathrm{SH}$ & 14 & 7 & 16 & 16 & 29 & 43 & 29 & 63 & 44 & 54 & 40 \\
\hline $\mathrm{TH}$ & 1556 & 1799 & 2668 & 2111 & 3231 & 7131 & 4043 & 4963 & 6409 & 8603 & 7935 \\
\hline TOTAAL & 21149 & 23687 & 30233 & 24800 & 36572 & 54790 & 49785 & 67707 & 71071 & 104371 & 96162 \\
\hline
\end{tabular}




\section{Bijlage 6 Aantal valnachten}

Tabel B6.1 Het aantal valnachten per camera-locatie in het studiegebied Doetinchem.

\begin{tabular}{|c|c|c|c|c|}
\hline Camera-locatie & Datum start & Datum eind & $\begin{array}{l}\text { Aantal } \\
\text { valnachten }\end{array}$ & Opmerking \\
\hline D1 & 2-7-2015 & $14-8-2016$ & 42 & \\
\hline D2 & $13-8-2015$ & $9-9-2015$ & 27 & \\
\hline D3 & 2-7-2015 & $30-7-2015$ & 54 & \\
\hline D4 & $2-7-2015$ & $9-9-2015$ & 69 & \\
\hline D5 & 2-7-2015 & $14-8-2015$ & 39 & \\
\hline D6 & 2-7-2015 & $14-8-2015$ & 43 & \\
\hline D7 & $2-7-2015$ & $8-8-2015$ & 37 & \\
\hline D8 & 2-7-2015 & $9-9-2015$ & 42 & \\
\hline D9 & $15-7-2015$ & $30-7-2015$ & 15 & Camera gestolen \\
\hline D10 & $2-7-2015$ & $14-8-2015$ & 40 & \\
\hline D11 & 2-7-2015 & $9-9-2015$ & 69 & \\
\hline D12 & 2-7-2015 & $11-8-2015$ & 40 & \\
\hline D13 & 2-7-2015 & $9-9-2015$ & 69 & \\
\hline D14 & 2-7-2015 & $9-9-2015$ & 69 & \\
\hline D15 & $13-8-2015$ & $15-8-2015$ & 2 & Camera defect \\
\hline D16 & $14-8-2015$ & $9-9-2015$ & 26 & \\
\hline D17 & $14-8-2015$ & $9-9-2015$ & 26 & \\
\hline D18 & $14-8-2015$ & 9-9-2015 & 26 & \\
\hline D19 & $13-8-2015$ & $15-8-2015$ & 2 & $\begin{array}{l}\text { Camera weggehaald i.v.m. } \\
\text { privéterrein }\end{array}$ \\
\hline D20 & $27-8-2015$ & $9-9-2015$ & 13 & \\
\hline D21 & $27-8-2015$ & $27-8-2015$ & 1 & Camera defect \\
\hline D22 & $14-8-2015$ & $9-9-2015$ & 26 & \\
\hline Totaal & & & 777 & \\
\hline
\end{tabular}

Tabel B6.2 Het aantal valnachten per camera-locatie in het studiegebied Biesbosch.

\begin{tabular}{lllll} 
Camera-locatie & Datum start & Datum eind & $\begin{array}{l}\text { Aantal } \\
\text { valnachten }\end{array}$ & Opmerking \\
B1 & $26-11-2015$ & $10-3-2016$ & 105 & \\
\hline B2 & $26-11-2015$ & $10-3-2016$ & 105 & \\
\hline B3 & $26-11-2015$ & $10-3-2016$ & 105 & Camera gestolen \\
\hline B4 & $26-11-2015$ & $10-3-2016$ & 105 & \\
\hline B6 & $26-11-2015$ & $26-1-2016$ & 61 & SD-kaart defect \\
\hline B7 & $26-11-2015$ & $10-3-2016$ & 105 & \\
\hline B8 & $26-11-2015$ & $10-3-2016$ & 105 & SD-kaart vol \\
\hline B9 & $26-11-2015$ & $10-3-2016$ & 85 & \\
\hline B10 & $26-11-2015$ & $10-3-2016$ & 105 & \\
\hline Totaal & $26-11-2015$ & $10-3-2016$ & 81 & 105 \\
\hline Gemiddeld per locatie & $26-11-2015$ & $10-3-2016$ & 1067 & \\
\hline
\end{tabular}




\section{Bijlage 7 Info-sheet buurtonderzoek}

\section{Onderzoek naar voorkomen wasberen in Nederland}

Juli 2015

\section{Aanleiding voor het onderzoek:}

In opdracht van het Ministerie voert Alterra-WUR een onderzoek uit naar het voorkomen van wasberen (Procyon lotor) in Nederland. Van oorsprong komen wasberen voor in Amerika. Begin vorige eeuw zijn ze naar Duitsland gehaald voor de pelsindustrie. Van daaruit zijn ze ontsnapt en losgelaten. Inmiddels is er een grote populatie wasberen in Duitsland die zich uitbreidt naar omliggende landen. Het ministerie wil graag weten in hoeverre er in Nederland al sprake is van een structurele populatie waarin voortplanting plaatsvindt, of dat het om incidentele waarnemingen gaat. Er komen momenteel steeds vaker meldingen van wasberen binnen onze landsgrenzen. De vondst nabij Doetinchem van drie (aangereden) dieren op korte afstand van elkaar kan hier echter wel op wijzen.

\section{Hoe ziet een wasbeer eruit?}

Wasberen hebben het formaat van een middelgrote hond en wegen ongeveer 7 kilo. Typerend zijn vooral de spitse snuit, het zwarte gezichtsmasker en de zwarte ringen op de staart (zie onderstaande foto's). Ze leven vooral in steden en bossen met wateren.

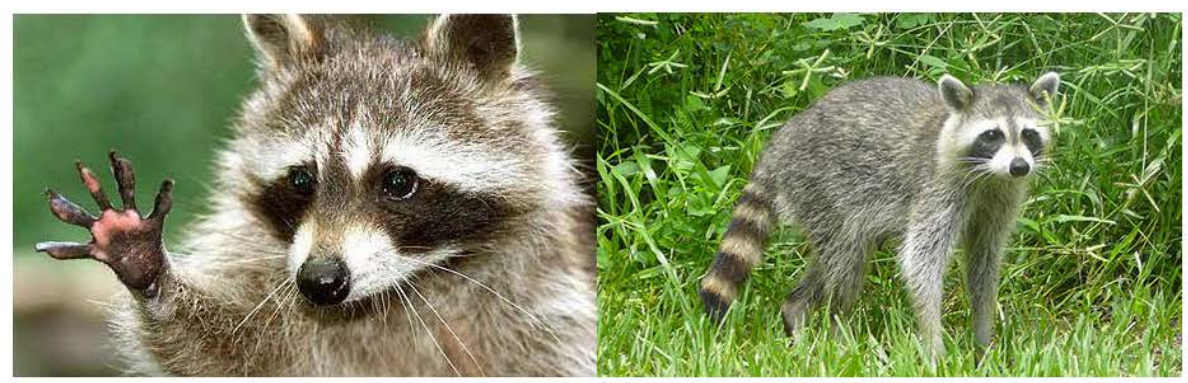

Foto's wasbeer (bron: internet).

\section{Hoe ziet het onderzoek rond Doetinchem eruit?}

Een belangrijk onderdeel van het onderzoek is het veldonderzoek naar het voorkomen van Wasberen rond de vindplaatsen van de drie recent dood gevonden Wasberen nabij Doetinchem. Alle waarnemingen zijn aan de zuid-zuidoostkant van Doetinchem gedaan, op relatief korte afstand van 
elkaar: circa 1,5 km tussen de waarneming op de Rekhemseweg en de Oude Terborgseweg, en circa $800 \mathrm{~m}$ tussen de waarneming op de Oude Terborgseweg en de Gaanderenseweg. De waarnemingen op de Rekhemseweg en de Oude Terborgseweg liggen (net) ten noorden van rijksweg A18. De waarneming op de Gaanderenseweg ligt (net) ten zuiden van de A18. Deze rijksweg wordt mogelijk dus door Wasberen gepasseerd.

We onderzoeken het voorkomen van Wasberen nabij Doetinchem op verschillende methoden. Met cameravallen proberen we dieren op de foto te krijgen. Deze camera's plaatsen we op strategische plaatsen. Ze maken een foto als er een dier voor langs loopt. Daarnaast doen we sporen onderzoek op modderige paden en onder bruggen etc. De pootafdruk is heel kenmerkend (zie bovenstaande foto). Ten slotte gaan we bewoners af om te vragen of ze wasberen hebben gezien. Ook zullen mensen of organisaties benaderd worden of ze meer weten van wasberen in de regio. Dit zal in de periode juli en augustus worden uitgevoerd.

Figuur: studiegebied nabij Doetinchem.

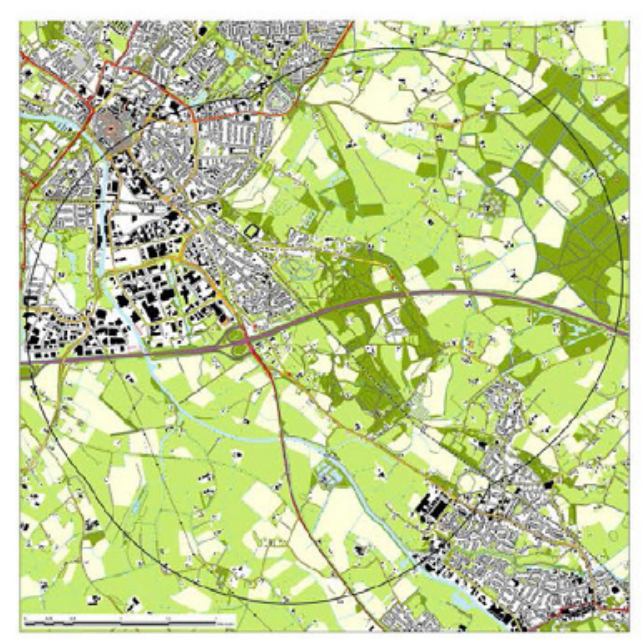

\section{Hoe kunt u helpen?}

Indien u wel eens wasberen heeft gezien in de regio of over wasberen hebt gehoord stellen we het op prijs als u contact met ons opneemt.

Hugh Jansman: hugh.jansman@wur.nl / 0317-485779.

Dennis Lammertsma: Dennis.lammertsma@wur.nl / 0317-486567 
Wageningen Environmental Research Postbus 47

6700 AA Wageningen

T 0317480700

www.wur.nl/environmental-research

Wageningen Environmental Research

Rapport 2764

ISSN 1566-7197
De missie van Wageningen University \& Research is 'To explore the potential of nature to improve the quality of life'. Binnen Wageningen University \& Research bundelen Wageningen University en gespecialiseerde onderzoeksinstituten van Stichting Wageningen Research hun krachten om bij te dragen aan de oplossing van belangrijke vragen in het domein van gezonde voeding en leefomgeving. Met ongeveer 30 vestigingen, 5.000 medewerkers en 10.000 studenten behoort Wageningen University \& Research wereldwijd tot de aansprekende kennisinstellingen binnen haar domein. De integrale benadering van de vraagstukken en de samenwerking tussen verschillende disciplines vormen het hart van de unieke Wageningen aanpak. 



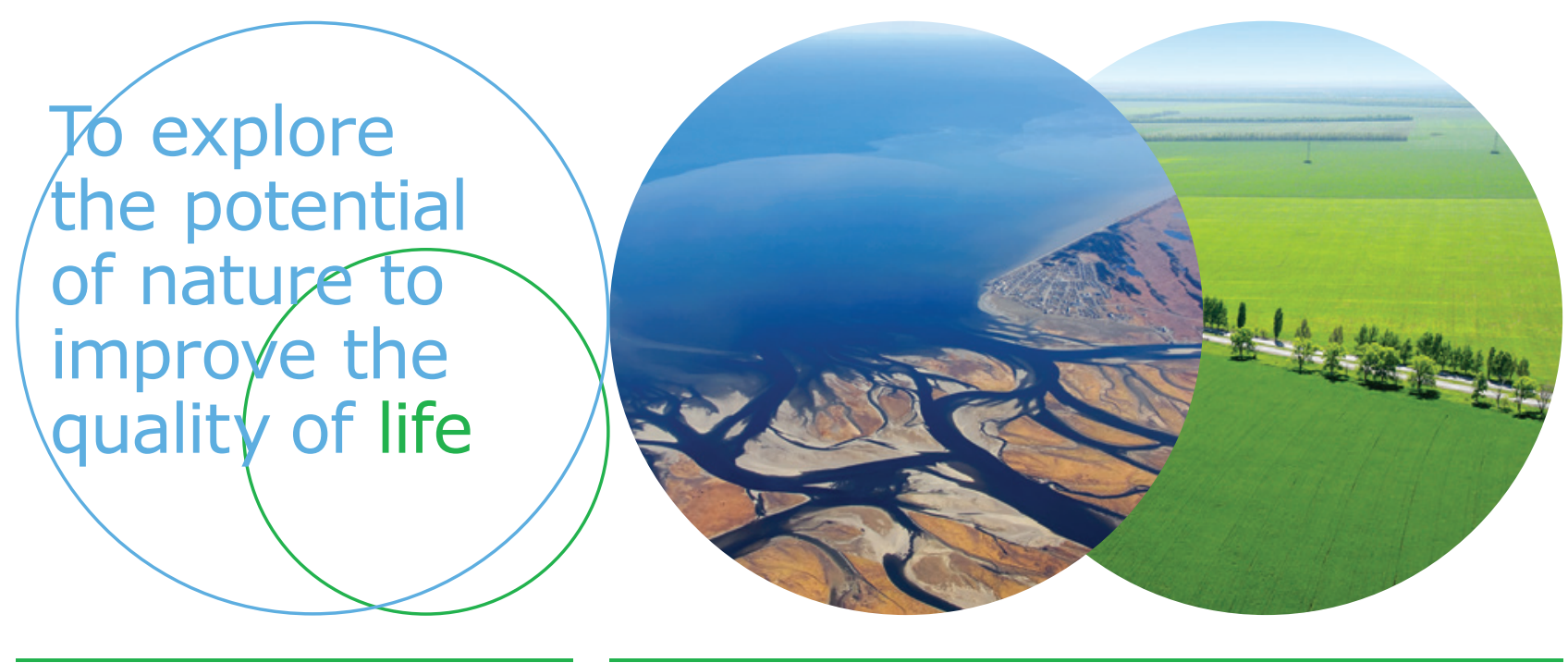

Wageningen Environmental Research Postbus 47

$6700 \mathrm{AB}$ Wageningen

T 317480700

www.wur.nl/environmental-research

Rapport 2764

ISSN 1566-7197
De missie van Wageningen University \& Research is 'To explore the potential of nature to improve the quality of life'. Binnen Wageningen University \& Research bundelen Wageningen University en gespecialiseerde onderzoeksinstituten van Stichting Wageningen Research hun krachten om bij te dragen aan de oplossing van belangrijke vragen in het domein van gezonde voeding en leefomgeving. Met ongeveer 30 vestigingen, 5.000 medewerkers en 10.000 studenten behoort Wageningen University \& Research wereldwijd tot de aansprekende kennisinstellingen binnen haar domein. De integrale benadering van de vraagstukken en de samenwerking tussen verschillende disciplines vormen het hart van de unieke Wageningen aanpak. 